REVISTA DE DERECHO UNED, NÚM. 21, 2017

\title{
LA FILIACIÓN NATURAL Y LA LIBRE INVESTIGACIÓN DE LA PATERNIDAD: EL AVANCE CIENTÍFICO COMO FACTOR EXIGENTE DE CAMBIOS JURÍDICOS
}

\author{
THE NATURAL FILIATION AND THE FREE INVESTIGATION \\ OF PATERNITY: SCIENTIFIC PROGRESS AS A DEMANDING \\ FACTOR OF LEGAL CHANGES
}

\author{
Premio de Artículos Jurídicos García Goyena \\ XVI Edición \\ Seleccionado para publicación
}

LAURA FERNÁNDEZ ECHEGARAY

\begin{abstract}
Resumen: La legislación española contempla únicamente como formas de filiación la natural y la adoptiva. En la etapa preconstitucional la investigación de la paternidad no estaba permitida. La paz familiar y la protección del matrimonio impedían que se pudiera demandar una filiación biológica no reconocida. Con ocasión de la CE, y de reformas legislativas posteriores, se implantó en España un sistema de acciones que permiten la constatación oficial de una filiación natural, a través de un pronunciamiento judicial. En la actualidad, ese sistema de acciones aún impone una serie de controles y limitaciones al acceso a la investigación de la paternidad. Entendemos que ha llegado el momento de ampliar esas garantías del derecho a la libre investigación de la filiación biológica. Para ello, será necesario realizar una serie de reformas legislativas que pasen por realzar y dar un valor absoluto a la llamada prueba biológica de ADN. Esta prueba equipara la verdad biológica con la jurídica Así lo proponemos en el presente trabajo. De igual forma, se requieren modificaciones en la legitimación de esas acciones, así como elevar a rango de Ley criterios jurisprudenciales plenamente consolidados por nuestros Tribunales.
\end{abstract}


Abstract: The Spanish legislation contemplates only as natural and adoptive forms of filiation. In the preconstitutional stage the investigation of paternity was not allowed. Family peace and the protection of marriage made it impossible to claim unrecognized biological filiation. On the occasion of the EC, and subsequent legislative reforms, a system of actions was implemented in Spain that allow the official confirmation of a natural filiation, through a judicial pronouncement. At present, this system of actions still imposes a series of controls and limitations on access to paternity research. We understand that the time has come to extend these guarantees of the right to free investigation of biological filiation. To do this, it will be necessary to carry out a series of legislative reforms that go on to enhance and give an absolute value to the so-called biological DNA test. This test equates the biological truth with the legal Thus we propose it with the present work. Likewise, changes in the legitimacy of these actions are required, as well as raising to the rank of Law, jurisprudential criteria fully consolidated by our Tribunals.

Palabras clave: Investigación, ADN, paternidad, demanda, límites.

Keywords: Research, DNA, paternity, demand, limits.

\section{LA FILIACIÓN NATURAL BIOLÓGICA Y SU INVESTIGACIÓN}

Podemos definir la institución de la filiación como la relación o vínculo que une a una persona con sus dos progenitores, o con uno solo de ellos ${ }^{1}$. Como idea originaria, la filiación deriva del nacimiento de un hijo a través de un puro hecho biológico. En base a esa procreación natural, nuestro ordenamiento jurídico se encarga de regular la distribución de derechos y obligaciones existentes entre progenitores y procreados o, lo que es lo mismo, entre padres e hijos. La relación jurídica de filiación, en la mayor parte de los casos, no trae aparejadas grandes complicaciones a la hora de reflejarla de forma oficial en el Registro Civil. Ahora bien, en otras ocasiones, esa determinación puede traer problemas a la hora de fijar el modo de establecerla, determinando en cada caso quién es el padre o quién es la madre del filiado.

${ }^{1}$ Díez Picazo, L., Gulllón Ballesteros, A.: Sistema de Derecho Civil. Derecho de Familia y Derecho de Sucesiones. Tecnos, Vol. IV, 10. a ed., 2006, pág. 223. 
En el tratamiento de la institución de la filiación, hasta la creación y aplicación de las técnicas de reproducción ${ }^{2}$ asistida en la década de los setenta, se tomaba como punto de partida únicamente el hecho biológico marcado por un acto sexual ${ }^{3}$. A raíz de una relación íntima entre dos sujetos, el hijo contaba con la determinación legal de una filiación biológica en la que, como mucho, podían derivarse problemas a la hora de constatar si había existido realmente esa relación sexual o, si fruto de esa situación afectiva, se había ciertamente engendrado a ese hijo. De lo anterior, podían desprenderse situaciones dirigidas a la necesidad de encontrar los medios probatorios que pu-

${ }^{2}$ El panorama reproductivo que estamos viviendo en la actualidad ha dado el pistoletazo de salida a otra de las grandes revoluciones en materia de filiación y, por tanto, en Derecho de familia. Está claro que la ciencia y los avances en biomédica van más rápido que el Derecho. Gracias a estos descubrimientos en materia de reproducción asistida han venido al mundo millones de niños que, de otra forma, nunca hubieran llegado a existir. Las situaciones logradas gracias a estas prácticas reproductivas, hace años resultaban sencillamente impensables. Hoy todo ello es posible gracias a estos imparables avances de la ciencia biomédica. A través de la pionera Ley 35/1988, de 22 de noviembre, sobre Técnicas de Reproducción Asistida (BOE núm. 282, de 24 de noviembre de 1988) y la posterior y actual Ley 14/2006, de 26 de mayo, sobre Técnicas de Reproducción Humana Asistida (BOE núm. 126, de 27 de mayo de 2006), España ha sido un país moderno y progresista en materia de reproducción artificial. LóPEZ GÁlvEZ y MORENO GARCÍA, revelan de forma desglosada la evolución en el tiempo de las distintas técnicas que han permitido que, desde el año 2012, gracias a la FIV, se hayan logrado cuatro millones de nacimientos.

Así lo describen literalmente en "¿Industria de la fertilidad" o respuesta a la búsqueda del hijo biológico?» En «Treinta años de reproducción asistida en España: una mirada interdisciplinaria a un fenómeno global y actual», Boletín del Ministerio de Justicia, Monográfico, Año LXIX, núm. 2179, junio 2015, pág. 245.

1978: Nacimiento de Louise Brown. (Reino Unido).

1983: Nace el primer niño procedente de un embrión congelado (Australia).

1984: Nace el primer niño procedente de una donación de óvulos (Australia).

1985: Primer parto gemelar tras congelación embrionaria (Australia).

1986: Primer embarazo tras TESA (Australia).

1988: Primeras referencias de embarazos tras GIFT (USA).

1990: Primer embarazo tras DGP (Reino Unido)

1992: Primer embarazo tras ICSI (Bélgica).

1992: Parto de una mujer de sesenta y dos años por TRA (Italia).

1997: Nacimiento por clonación de la oveja Dolly (Reino Unido).

2012: Se llega a los cuatro millones de nacimientos a través de FIVIICSI).

${ }^{3}$ En opinión de TAmayo Haya, S., la facultad de acudir a las vías legales de determinación de la filiación han traído un cambio en relación con los presupuestos sobre los que tradicionalmente vino conceptuándose la filiación. Matiza la autora explicando que, la distinción entre «engendramiento» como dato natural, y "filiación» como institución jurídica, arroja que el elemento necesario para determinar la filiación va a variar desde el momento en que será posible determinarla a través de un puro acto de voluntad, alejado ya de la necesidad de relación sexual o vínculo biológico: en «Reproducción Asistida, doble maternidad legal y novedades jurisprudenciales en la determinación de la filiación» en La maternidad y la paternidad en el siglo XXI. Comares, 2015, pág. 60 . 
dieran acreditar lo anterior. Esa dificultad de prueba descansaba, como es evidente, en el factor relativo a la intimidad que preside las relaciones sexuales. En otros tiempos, la parte que pretendía la determinación judicial de una filiación debía valerse únicamente de prueba indiciaria consistente en documentos o testimonios de terceros que poseían información relativa a la existencia de esa posible relación afectiva entre los involucrados (aportación de fotografías, facturas de hotel, pasajes de viajes o prueba testifical).

En relación con lo anterior, el establecimiento de la filiación partía de dos singulares premisas:.

La primera, estaba basada en el hecho de que la maternidad siempre era posible determinarla atendiendo al simple hecho del parto ( $m a-$ ter semper certa est). Tradicionalmente, la mujer que alumbraba era indiscutiblemente la madre de ese hijo. De ahí que esta máxima de derecho romano no admitiera prueba en contrario. Sin embargo, con la aparición de las técnicas de reproducción asistida heterólogas ${ }^{4}$, este principio entró en una profunda crisis. El hecho de que gracias a la tecnología, hoy en día, una mujer pueda gestar y alumbrar un hijo partiendo de la previa implantación en su útero de un óvulo aportado por otra mujer, explica el decaimiento de este aforismo. La ruptura del nexo entre lo biológico y lo genético ha supuesto que los roles de madre biológica y madre genética puedan atribuirse a mujeres distintas.

La segunda premisa, consistía en la determinación de la paternidad. Esta venía siendo jurídicamente atribuida al varón que había realizado el acto procreador con la parturienta en un momento probable de la concepción del recién nacido. Esto, en realidad, estaba rodeado de un velo de misterio ${ }^{5}$ puesto que la certeza no estaba asegurada. De ahí que el legislador partiera de la valoración de lo razo-

\footnotetext{
${ }^{4}$ Se ha convertido en opinión común la consideración de que la utilización de este tipo de técnicas ha supuesto la crisis del actual sistema basado en dos tipos de filiación: la natural y la adoptiva. Se entiende necesario introducir una nueva forma de filiación basada en la llamada voluntad procreacional, que descansa en un consentimiento informado. Así lo afirman, entre otros, GonzÁlez Pérez dE CASTRo, M.: «La verdad biológica en la determinación de la filiación», Dykinson, Madrid, 2013, pág. 251; Kemelmajer de Carlucci, A., Herrera, M., Lamm, E., en «Ampliando el campo del derecho filial en el derecho argentino. Texto y contexto de las técnicas de reproducción humana asistida». Revista de Derecho Privado, Argentina, núm. 1, 2012, pág. 5.; Roca Trías, E.: «Filiación asistida y protección de derechos fundamentales», Derecho y Salud, núm. 7, 1999, pág. 3. TamaYo HaYA, S.: «Reproducción Asistida, doble maternidad legal y novedades jurisprudenciales en la determinación de la filiación» en La maternidad y la paternidad en el siglo XXI. Comares, 2015, pág. 60.

${ }^{5}$ Díez Picazo, L., Gullón Ballesteros, A.: Sistema de Derecho Civil. Derecho de Familia y Derecho de Sucesiones, ob. cit., pág. 223.
} 
nable a la hora de fijar sus reglas de filiación. Nos referimos a la apreciación de la estadística consistente en que lo común es que el esposo sea el padre biológico de los hijos de su esposa. De lo anterior, se llegó a la regla de "pater vero is est quem nuptiae demostrant», establecida como la presunción de paternidad del marido (art. $116 \mathrm{CC})^{6}$.

Hoy en día, con ocasión del avance de la ciencia y la tecnología, tanto el hecho de la maternidad como de la paternidad, pueden quedar directamente acreditados a través de una sencilla prueba. Nos referimos a la denominada prueba biológica que despeja la incógnita con efecto de acreditación directa. La fiabilidad de esta práctica, consistente en el contraste de las muestras del material genético del progenitor y el hijo, arroja un resultado prácticamente certero ${ }^{7}$. Se trata de la denominada prueba de $\mathrm{ADN}^{8}$. El ácido desoxirribonucleico es el tipo de molécula más complejo que se conoce. Es el lugar de nuestro organismo donde reside la información genética ${ }^{9}$. Este material genético es el que se transmite de padres a hijos. Su estructura contiene las instrucciones que necesita un organismo para nacer y desarrollarse a partir de la primera célula. Se organiza en unidades más pequeñas llamadas genes ${ }^{10}$.

En otros tiempos, además de no contar con medios tan avanzados como en la actualidad, España, en materia de filiación, aplicaba una

${ }^{6} \mathrm{El}$ art. 116, establece que «Se presumen hijos del marido los nacidos después de la celebración del matrimonio y antes de los trescientos días siguientes a su disolución o a la separación legal o de hecho de los cónyuges». A pesar de lo anterior, el artículo 117 CC permite destruir esa paternidad en los supuestos en que el hijo ha nacido dentro de los ciento ochenta días siguientes a la celebración del matrimonio. Para ello, el esposo deberá realizar una declaración auténtica en contrario, formalizada dentro de los seis meses siguientes al conocimiento del parto. Respecto a esto, se exceptúa que el esposo hubiera reconocido la paternidad, expresa o tácitamente, o hubiese conocido el embarazo de la mujer con anterioridad a la celebración del matrimonio, salvo que, en este último supuesto, la declaración auténtica se hubiera formalizado con consentimiento de ambos, antes del matrimonio o después del mismo, dentro de los seis meses siguientes al nacimiento del mismo.

${ }^{7}$ Afirma LORENTE LóPEZ, M. ${ }^{a}$, C., que la prueba genética juega un papel fundamental en los procesos civiles de filiación puesto que los avances científicos han conseguido que estas pruebas arrojen resultados certeros: en «La prueba genética y los derechos fundamentales de la persona en los procesos civiles de filiación, paternidad y maternidad». Revista Doctrinal Aranzadi, Cizur Menor, 2015, pág. 4.

${ }^{8}$ Acido Desoxirribonucleico.

${ }^{9}$ Quesada GonzÁlez, M. ${ }^{\text {a }}$ C.: «La prueba de ADN en los procesos de filiación». Anuario de Derecho Civil, II, 2005, pág. 1.

${ }^{10}$ Fue en el año 1953, cuando Francis Crick y James Watson descubrieron la estructura en doble hélice en la que aparece el ADN. A partir de ese momento el trabajo constante de los científicos ha permitido obtener resultados de enorme valor para la sociedad http://www.andaluciainvestiga.com/espanol/cienciaAnimada/sites/dna/ dna.swf 
discriminatoria tradición jurídica que partía de la radical distinción de los hijos, dependiendo de la situación civil en la se producía su nacimiento. No se daba el mismo tratamiento jurídico al hijo que nacía dentro del matrimonio de sus padres, que al que nacía fuera de él. Dependiendo de una u otra situación, el otorgamiento de derechos era distinto y, por ende, la institución de la filiación también. Al hijo nacido fuera del matrimonio se le consideraba como «ilegitimo» y al nacido dentro como «legítimo». De este dato partía la distinción de la llamada «filiación legítima» o «filiación ilegítima». La ilegitimidad llevaba aparejada una connotación peyorativa que imputaba a los hijos la forma de procreación "pecadora» de sus padres ${ }^{11}$. La mayor consecuencia que esto llevaba aparejado era la diferencia de organización de una serie de medidas de protección de la familia. A su vez, dentro de la filiación ilegítima podíamos encontrar subgrupos en los que, además, aparte de estar ya reprochados por haber nacido fuera del matrimonio de sus padres, había que distinguir cuál era el motivo que había llevado a los progenitores a procrear fuera del matrimonio; si esa unión no se podía celebrar por prohibiciones o impedimentos matrimoniales, el reproche de los hijos era aún mayor. Nos referimos a hijos del adulterio o del incesto ${ }^{12}$. La tradición jurídica española denominaba entonces, "hijos naturales» a los que habían nacido de padres habilitados para el matrimonio entre los que no mediaban impedimentos legales, o los «no naturales» en los que sí existían esos impedimentos. La discriminación de derechos entre los subgrupos era considerable.

Dejando atrás esta antigua concepción de la filiación, con la evolución de los tiempos, se consiguió implantar en nuestro país un nuevo modelo en el que se olvidó el común y habitual vocablo peyorativo de «bastardos», con el que se identificaba a los hijos no matrimoniales. En consecuencia, en nuestro sistema de filiación se implantaron dos principios básicos imperativos:

${ }^{11}$ Díez Picazo, L., Gullón Ballesteros, A.: Sistema de Derecho Civil. Derecho de Familia y Derecho de sucesiones, ob. cit., pág. 223.

${ }^{12}$ Opina Durán Rivacoba, R., que ante situaciones como el incesto o aquellas situaciones en las que se daba una negligencia del padre, se ofrecían una serie de soluciones basadas en el favor fili, que aminoraban un fundamentalismo fisiológico, a veces más lesivo que beneficioso. Consistía en reconocer como padre a quien se hacía cargo de esa familia. Esto significa que, en la órbita jurídica, no es necesario reputar siempre como progenitor al ascendiente carnal. En palabras del autor, «la verdad biológica sirve como premisa básica, pero no absoluta o excluyente»: en «El anonimato del progenitor». Revista Doctrinal Aranzadi, Civil-Mercantil, núm. 3, Parte Estudio, Pamplona, 2004, págs. 1 y 2. 
1. Se instauró como regla básica la igualdad entre todos seres humanos y la inadmisibilidad de cualquier idea de que lleve implícito las discriminaciones basadas en el origen familiar. Esta línea fue la que acogió nuestra Constitución de 1978, en su consagrado principio de igualdad del artículo 14 CE (nadie puede ser discriminado por razón de nacimiento). Independientemente de esto, nuestro Código Civil mantuvo, y hoy en día conserva, la distinción entre filiación matrimonial y no matrimonial aunque ya no afecta a los derechos o efectos para con los hijos. Únicamente se conserva en relación al procedimiento de acceso de cada forma de filiación al Registro Civil. De esta forma, el artículo 108 CC establece que la filiación puede tener lugar por naturaleza y por adopción. Recoge que la filiación por naturaleza puede ser tanto matrimonial ${ }^{13}$ como no matrimonial ${ }^{14}$. Todas ellas producen los mismos efectos y la única diferencia que se contempla en esa distinción es de carácter exclusivamente funcional.

2. En la misma línea, otro de los principios constitucionales protagonistas en materia de filiación fue, sin duda alguna, la inclusión del artículo 39 de la Constitución Española (CE). En él se establece que los poderes públicos asegurarán la protección integral de los hijos, iguales estos ante la ley con independencia de la filiación, y de las madres, cualquiera que sea su estado civil. Una novedad importantísima e indiscutible en esta mate-

${ }^{13}$ La filiación matrimonial quedará determinada por la inscripción en el Registro Civil del nacimiento del niño, junto la certificación del matrimonio de los padres (queda a salvo el acceso a través de una sentencia firme para los casos en que previamente se haya instado la acción de reclamación matrimonial de paternidad y así lo haya determinado un juez).

${ }^{14}$ La determinación de la filiación no matrimonial, contemplada en la tradicional redacción del artículo 120 CC, establece que podrá realizarse vía reconocimiento, realizado en documento público, en testamento, o ante el Encargado del Registro Civil, o a través de la tramitación de un expediente iniciado en el Registro Civil. De igual forma, queda abierta la vía de que se determine con ocasión de la sentencia judicial dictada en un procedimiento de reclamación de paternidad extramatrimonial. En este punto hay que mencionar que, con ocasión de la entrada en vigor de la Ley 19/2015, de 13 de julio, de Medidas de Reforma Administrativa en el ámbito de la Administración de Justicia y del Registro Civil, se ha reformado este artículo 120 CC añadiéndose un párrafo más, que señala que también podrá determinarse la filiación no matrimonial «en el momento de la inscripción del nacimiento, por declaración conforme realizada por el padre en el correspondiente formulario oficial a que se refiere la legislación del Registro Civil». De igual forma, el artículo 119 CC, relativo a nacimientos acaecidos con anterioridad al momento de la celebración del matrimonio, otorga la posibilidad de que la filiación adquiera el carácter de matrimonial desde la fecha del matrimonio de los progenitores, siempre que el hecho de la filiación quede legalmente determinado. 
ria fue, sin duda alguna, la redacción del apartado segundo de este artículo $39 \mathrm{CE}$. A través de este se instauró el principio constitucional de investigación de la paternidad ( LLa ley posibilitará la investigación de la paternidad»). Con esto se introducía en nuestro sistema jurídico la posibilidad de indagar e investigar la filiación y, en consecuencia, se contemplaba la opción de desvelar y legalizar filiaciones antes del todo imposibles. Hasta ese momento, en España se impedía la búsqueda de paternidades en defensa de los padres. Se entendía que si se permitían las investigaciones de paternidad, se corría el riego de ver interpuestas numerosas demandas de filiación de carácter injusto, que podían tachar el buen nombre de muchos ciudadanos ${ }^{15}$. Se entendía que debía protegerse de forma suprema la paz familiar, dándose una importancia absoluta a la institución de la familia.

Como es lógico, la introducción en la CE de los artículos 14 y 39.2, hizo necesaria la implantación de un nuevo sistema de filiación, siendo necesaria una profunda revisión del derecho de familia en nuestro país. Esta se llevó a cabo a través de la Ley 11/1981, de 13 de mayo ${ }^{16}$, por la que se reformaba el Código Civil, no sólo en materia de filiación sino, de igual forma, en materia de patria potestad y de régimen económico matrimonial. Fruto de lo anterior, hoy en día nuestro ordenamiento jurídico reconoce expresamente el derecho de las personas a investigar sus orígenes biológicos. Para ello ha instaurado un régimen de acciones de filiación: acción de reclamación de filiación (será necesario distinguir entre si la filiación que se reclama es de tipo matrimonial o no matrimonial, así como si se da la existencia o no de posesión de estado ${ }^{17}$ entre el progenitor y el hijo), acción de impugnación y acción mixta.

${ }^{15}$ Como explica Durán Rivacoba, R., como consecuencia de la conducta de los progenitores, los perjuicios recaían en la descendencia. No había en esa época anterior un margen legal para imponer a esos progenitores sus obligaciones y responsabilidades respecto de los hijos que sufrían desagravios como víctimas inocentes, triunfando un axioma de poca seriedad en una cultura moderna y avanzada: en « $E l$ anonimato del progenitor», ob. cit., pág. 1. En este sentido, al establecer el legislador el requisito de control de viabilidad previo de la demanda de filiación, lo que implica la aportación de un mínimo indicio de prueba sobre la relación sexual, LORENTE LóPEZ, M. ${ }^{a}$, C., entiende que el legislador ha querido desincentivar a personas poca escrupulosas que interpongan acciones de filiación con el objeto de conseguir otros intereses distintos que no descansen en la búsqueda de la verdad biológica: en $\mathrm{La}$ prueba genética y los derechos fundamentales de la persona en los procesos civiles de filiación, paternidad y maternidad, ob. cit., pág. 2.

${ }^{16}$ BOE núm. 119, de 19 de mayo.

${ }^{17}$ A pesar de que la reforma de 1981 aludiera varias veces a este concepto, y así se cita en varios preceptos en nuestro ordenamiento jurídico (art. 113 CC, 767.3 LEC), 
Esto desvela que en nuestro país ya es un hecho consagrado la protección del derecho a conocer los orígenes biológicos de las personas. Significa que, por lo que se refiere tanto a los supuestos relativos a la filiación biológica o natural, como a la filiación adoptiva ${ }^{18}$, España ya cuenta con un sistema de reconocimiento legal expreso. A pesar de lo anterior, en nuestro ordenamiento jurídico, hoy en día, existen situaciones concretas donde la prohibición del derecho a conocer los orígenes está expresamente contemplada. Es el caso de los nacimientos habidos a través de técnicas de reproducción asistida de tipo heterólogo (con material genético aportado por donante de esperma o de óvulos $)^{19}$ en las que la defensa del anonimato del donante

no se determina lo que por tal debe entenderse. Tanto la jurisprudencia como la doctrina ha reflejado que la posesión de estado viene a consistir en una apariencia social de relación parental o maternal con el individuo. Para reconocerse tradicionalmente se ha exigido la presencia de «nomen, fama y tractatus», así como la convivencia continuada e ininterrumpida. La idea de posesión enfocada a los estados civiles y a la filiación, tal y como establecen DíEz-PICAZo y GULLón BALLESTERos, alude a una situación de apariencia que a través de actos concluyentes crea una apariencia jurídica que sirve para declarar, por lo menos inicial o provisionalmente, la realidad de la que es reflejo. Díez Picazo, L., Gullón Ballesteros, A.: Sistema de Derecho Civil, Derecho de Familia y Sucesiones, Vol. IV, Tecnos, Madrid, 2006, pág. 227.

${ }^{18}$ El derecho a conocer los orígenes biológicos también está permitido en materia de adopción. Con ocasión de la entrada en vigor de la Ley 54/2007, de 28 de diciembre de Adopción Internacional (BOE núm. 312, de 29 de diciembre), a través de su art. 12, se produjo la reforma del art. $180 \mathrm{CC}$ en el que se añadió un quinto párrafo que recogió de forma legal y expresa el derecho de los hijos adoptados a poder conocer la identidad de sus padres biológicos. Este derecho ha sido potenciado con ocasión de la Ley 26/2015, de 28 de julio, de Modificación del Sistema de Protección a la Infancia y a la Adolescencia (que incluye un nuevo $6 .^{\circ}$ párrafo extensivo del derecho) (BOE núm. 180, de 29 de julio). LORENTE LóPEZ, M. ${ }^{a}$ C.: La prueba genética y los derechos fundamentales de la persona en los procesos civiles de filiación, paternidad y maternidad», ob. cit., págs. 2, 3 y 5.

${ }^{19}$ El artículo 5.5 de la Ley 14/2006, de 26 de mayo, de Técnicas de Reproducción Humana Asistida (LTRHA) establece que «La donación será anónima y deberá garantizarse la confidencialidad de los datos de identidad de los donantes por los bancos de gametos, así como, en su caso, por los registros de donantes y de actividad de los centros que se constituyan. Los hijos nacidos tienen derecho por si o por sus representantes legales a obtener información general de los donantes que no incluya su identidad. Igual derecho corresponde a las receptoras de los gametos y de los preembriones.

Sólo excepcionalmente, en circunstancias extraordinarias que comporten un peligro cierto para la vida o salud del hijos o cuando proceda a las Leyes procesales penales, podrá revelarse la identidad de los donantes, siempre que dicha revelación sea indispensable para evitar el peligro o para conseguir el fin legal propuesto. Dicha revelación tendrá carácter restringido y no implicará en ningún caso publicidad de la identidad de los donantes». A su vez, el artículo 8.3 de citada Ley recoge que «La revelación de la identidad del donante en los supuestos en que proceda con arreglo al artículo 5.5 de esta Ley, no implica, en ningún caso, determinación legal de la filiación».

De todo lo anterior se desprende que, en virtud de la aplicación de citada norma, en España, las donaciones de material genético reproductor son indudablemente anónimas. 
de gametos prevalece frente al derecho de hijo a saber sobre sus orígenes genéticos.

Independientemente de lo anterior, en lo que se refiere a la investigación de la paternidad o maternidad biológica natural, algunas cuestiones plasmadas en su reglamentación reflejan que ese derecho no puede entenderse como absoluto. Decimos esto porque, en nuestra regulación relativa a estas acciones de filiación, se contemplan una serie de controles y premisas que podrían calificarse de limitativos de ese derecho. De esta forma, podemos entender que los problemas que pueden limitar el derecho a conocer la verdadera filiación biológica de una persona descansan, por una parte, en el necesario control de viabilidad previo a la admisión a la demanda de filiación, y por otras, en la negativa del demandado a someterse a la prueba de ADN, así como la extensa legitimación prevista para estas acciones $^{20}$.

\section{PRINCIPIO DE CONTROL PREVIO DE VIABILIDAD DE LAS DEMANDAS DE FILIACIÓN}

Nuestro Código Civil otorga regulación a las correspondientes acciones de filiación a través de sus artículos 131 y siguientes. De igual forma, en relación con los procesos de paternidad y maternidad, la Ley $1 / 2000$, de 7 de enero, de Enjuiciamiento Civil ${ }^{21}$ (LEC), dedica a esta materia sus artículos 764 y siguientes. Hay de señalar que, con ocasión de la entrada en vigor de la citada Ley 26/2015, de 28 de julio, de Modificación del Sistema de Protección a la Infancia y a la Adolescencia, se ha producido una reforma legislativa relativa a la filiación. Fruto de la anterior, han quedado modificados varios artículos del Código Civil ${ }^{22}$.

${ }^{20}$ LORENTE LÓPEZ, M. ${ }^{\text {a }}$ C.: La prueba genética y los derechos fundamentales de la persona en los procesos civiles de filiación, paternidad y maternidad, ob. cit., págs. 2, 3 y 5 .

${ }^{21}$ BOE núm. 7, de 8 de enero de 2000.

${ }^{22}$ Destacamos la reforma del artículo 9, en sus apartados 4, 6 y 7. Estos preceptos, relativos a la ley aplicable en relación con la determinación y el carácter de la filiación por naturaleza o por adopción, así como en materia de protección de menores, se adecúan al contenido del Convenio de la Haya, de 19 de octubre de 1996, relativo a la competencia, ley aplicable, reconocimiento, ejecución y cooperación, en materia de responsabilidad parental y de medidas de protección de los niño (https://www. hcch.net/es/instruments/conventions/full-text/?cid=70). 
Centrándonos ya en el requisito relativo al control de viabilidad previo de las demandas de filiación, el artículo $767.1^{23}$ de la LEC, que prácticamente reproduce el contenido del derogado ${ }^{24}$ artículo $127 \mathrm{CC}$, establece este principio ya consagrado de los procedimientos de filiación. Este artículo fue implantado con el objeto de instaurar un sistema equilibrado ${ }^{25}$ entre los intereses que se pretenden hacer valer en el procedimiento judicial. La valoración del principio de prueba tiene un inevitable componente subjetivo de apreciación que se encomienda al prudente arbitrio judicial, a través de un pronunciamiento razonado y no arbitrario, que finalmente dará lugar a la admisión o inadmisión de la demanda ${ }^{26}$. Con este requisito el legislador ha pretendido claramente desalentar a posibles litigantes cuyos intereses reales no descansan en la investigación de la verdad biológica. Este es el objetivo principal de estos procedimientos de filiación pero, por el contrario, pueden darse situaciones en las que las intenciones de los litigantes descansen en otro tipo de intereses. En este sentido, el TS., a través del Auto de 4 de febrero de $2015^{27}$, recoge que el reconocimiento de la libre investigación de la paternidad genera el riesgo de la tramitación en procesos inspirados en propósitos no merecedores de protección jurídica ${ }^{28}$.

Con independencia de lo anterior, entendemos que el control de viabilidad previo de la demanda de filiación, no puede consistir, de ninguna manera, en una prueba absoluta que busque la plena convicción de juzgador sobre la petición instada en la demanda. Para lo anterior ya existen fases procedimentales concretas en la que se instaura

${ }^{23} \mathrm{Su}$ contenido literal recoge que «En ningún caso se admitirá la demanda sobre determinación o impugnación de la filiación si con ella no se presenta un principio de prueba de los hechos en que se funde».

${ }^{24} \mathrm{El}$ art. 127 CC fue derogado con ocasión de la entrada en vigor de la Ley 1/2000, de 7 de enero, de Enjuiciamiento Civil.

${ }^{25}$ RuIz Moreno, J. M.: El proceso especial de filiación, paternidad y maternidad. La Ley, Madrid, 2000, pág. 93.

${ }^{26}$ Ibídem. pág. 98.

27 (PROV 2015, 43487).

${ }^{28}$ En relación con una demanda de acción de reclamación de paternidad, el Tribunal expresó en su fallo que «La jurisprudencia, en el cumplimiento de la función que le atribuye el artículo 1 del Código Civil, ha entendido que la norma actualmente contenida en el artículo 767, apartado 1, de la Ley de Enjuiciamiento Civil, en cuanto impone un requisito de procedibilidad, ha de ser objeto de interpretación flexible, pues no trata de condicionar la admisión de la demanda a una prueba anticipada de los hechos en los que la misma se funde, ni siquiera a la inicial demostración de su verosimilitud o apariencia de buen derecho- como se exige para el otorgamiento de una medida cautelarsino establece un instrumento-en forma de exigencia de principio de prueba, que está destinado a preservar la seriedad de este tipo de procesos; y que sin embargo, no se considera deficientemente utilizado por el hecho de que, finalmente, la demanda no resulte estimada». 
el mecanismo contradictorio de la fase probatoria ${ }^{29}$. En base a ese requisito de admisión, hay que destacar que, durante las últimas décadas, ha sido una práctica común necesaria que, junto a la demanda, se acompañen como prueba documental bien fotografías ${ }^{30}$, facturas de hotel, reservas de viajes y, sobre todo, el anuncio previo de la realización de prueba testifical en el plenario. En este aspecto, es usual que se anuncien los datos de identificación personal de los testigos propuestos sobre los que se interesa testimonio. De igual forma, es recomendable que se ofrezca información relativa a los hechos de los que pueden ser conocedores estos sujetos. Otra forma habitual de cumplir con ese anuncio testifical, se realiza a través de declaraciones notariales ${ }^{31}$, realizadas por los testigos propuestos, consistentes básicamente en recoger por escrito los hechos de los que son conocedores.

Otra opción cada vez más más utilizada es la aportación de pruebas biológicas realizadas por laboratorios privados. Es evidente que estas serán admitidas con la demanda de filiación, aunque esto no impide a las partes y al propio juez encargado del asunto, instar las correspondientes pruebas biológicas ante el Instituto de Medicina Legal, adscrito a los juzgados. El juez decide sobre la admisión de la demanda si entiende que hay acreditado un principio mínimo de «posibilidad de prue$b a »$ de relación sexual entre los implicados, en el momento de la concepción de la persona respecto a la que se insta la demanda.

Independientemente de lo anterior, este control previo de viabilidad de la demanda, en la práctica real, no es estricto ni inflexible, salvo excepciones muy concretas. Recientemente el TS, ha fallado a favor de la falta de admisión de la demanda de paternidad, en relación con algunos asuntos de gran repercusión mediática, oficial e institucional $^{32}$, por razón de la identidad de la persona demandada. Lo cierto es

${ }^{29}$ Artículos 281 y ss. de la LEC.

${ }^{30}$ SAP de Málaga núm. 9/2014, de 3 de enero (PROV 2014/277887).

${ }^{31}$ SAP de Asturias núm. 7/2015, de 20 de enero (PROV 2015, 69915).

32 Uno de estos asuntos de referencia es relativo a la interposición de una demanda de paternidad contra el Monarca, Juan Carlos I de Borbón, por un ciudadano español. El TS, dictó Auto desestimando la admisión de la demanda alegando que no se acompañaba a la misma ningún principio de prueba. Lo anterior, fue acordado a pesar de que se acompañaban una serie de cartas enviadas a la Casa Real, así como una prueba de ADN parcial, realizada por un perito criminalista. En este caso, a pesar de solicitarse la realización de la prueba biológica, el TS determinó la inadmisión de la demanda por no aportarse principio de prueba. Con posterioridad, se interpuso recurso de amparo ante el TC, que desestimó el mismo alegando que el recurrente no había agotado debidamente los medios de impugnación en la vía judicial, precisando que debía haber interpuesto antes el incidente de nulidad de actuaciones previsto en el art. 241. De la Ley del Poder Judicial. Además de lo anterior, se da un dato añadido; por la vecindad civil del demandante, era de aplicación el Código Civil Catalán, 
que, con independencia de las anteriores excepciones, hoy en día está jurisprudencialmente asentado que para la admisión bastará con el ofrecimiento de la realización de la prueba ${ }^{33}$ biológica. Entendemos la lógica de lo anterior. En realidad, el principio de prueba al que se refiere el artículo 767.1, debe ser valorado por el juzgador de instancia. Pensemos, por ejemplo, en casos de personas adultas, de treinta o cuarenta años ${ }^{34}$, que deciden ya en su madurez interponer la acción de reclamación de paternidad contra el que piensan que es su padre (esta acción, en esos casos, es imprescriptible por lo que podrá interponerse en cualquier momento de la vida de ese hijo). En este supuesto podrían existir dos cuestiones que, de no ser por la flexibilidad jurisprudencial otorgada a este principio de prueba, impediría a muchas personas acceder al procedimiento. Pensemos en casos en que la madre de esta persona ya adulta ha fallecido, está ausente o sencillamente no comparte que su hijo interponga dicha acción judicial ¿Qué principio de prueba podría aportar ese hijo que refleje una posibilidad de relación sexual o efectiva llevada a cabo treinta años atrás? Sin duda la posibilidad probatoria sería excesivamente complicada.

Hoy en día la tecnología es muy avanzada. La toma de fotografías es una práctica reiterada en nuestra sociedad. Fotografiar todos los momentos de nuestra vida es un hecho normal. Contamos con numerosos medios tecnológicos, telemáticos y de comunicación que hacen que la difusión de nuestras fotografías sea muy sencilla. Por el contrario, hace treinta o cuarenta años, esto era mucho más remoto en uso. Entendemos que sería una labor altamente complicada para estas personas, hacerse con pruebas sentimentales relativas a situaciones intimas vividas tantos años atrás. La solución a estos supuestos descansa precisamente en la posibilidad jurídica de que, en la demanda, se anuncie la solicitud de la prueba biológica, sin perjuicio de ratificar su petición en el momento procesal oportuno.

que no exige este control de viabilidad previo para la admisión de las demandas de filiación. El recurrente anunció su intención de acudir al TEDH. Europa Press: «El Constitucional rechaza la demanda de paternidad de Solá contra el rey Juan Carlos». Publicado el 15 de mayo de 2015. http://www.publico.es/politica/constitucional-rechaza-demanda-paternidad-sola.html.

${ }^{33}$ Señala OcAÑA RoDRíGUEZ, A., que la prueba biológica, desde luego, nunca va a ser impertinente. No es inútil desde el momento en que puede lograr el resultado apetecido. Se refiere a los hechos alegados y controvertidos. Podrá en todo caso ser superflua o abundante, motivo nunca suficiente para excluirla: En «La sentencia del Tribunal Constitucional de 17 de enero de 1994 sobre filiación, desde una perspectiva procesal». PJ, núm. 36, 1994, pág. 129.

${ }^{34} \mathrm{La}$ acción de reclamación de filiación, en el caso de ser extramatrimonial y sin posesión de estado, de ser interpuesta por el hijo, es imprescriptible (art. 133 CC). 
A tal fin, entendemos que, en la realidad práctica, este requisito de control de viabilidad previo de las demandas de filiación, no es común que atente ni vulnere el ejercicio del derecho de los hijos a investigar la paternidad. Como decimos, nuestros tribunales, de forma lógica, suelen aceptar la demanda bastando el ofrecimiento de realización de la prueba biológica. Ahora bien, con independencia de ello, no hay que olvidar que esa práctica no deja de ser puramente potestativa del tribunal y, en consecuencia, pueden seguir dándose casos como el destacado a nivel institucional antes referido, $\mathrm{u}$ otros similares. Es por ello que entendemos que lo más sensato es que, aun a pesar de su consolidación jurisprudencial, el criterio se eleve definitivamente a rango de ley. Creemos que ha llegado el momento de que ese criterio de admisión de la demanda adquiera el carácter automático desde el mismo momento en que la parte demandante anuncie la solicitud de dicha prueba de ADN.

En conclusión, proponemos una necesaria reforma del Derecho, concretamente del art. 767.1 LEC, en lo relativo a la inclusión legal expresa de la admisión automática de las demandas de filiación en las que se solicite una prueba biológica como medio probatorio de carácter directo. Existiendo una sencilla prueba directa que esclarece la verdad biológica, no podemos compartir que, en algunos casos especialmente fallados por el $\mathrm{TS}^{35}$, se haya inadmitido a trámite la demanda a pesar de anunciarse la misma. El hecho de considerar que no hay indicio alguno de relación sexual inicial no puede sustituir la obtención de la verdad biológica/jurídica. Si la ciencia nos ha facilitado una prueba directa de esclarecimiento de hechos demandados, apartemos de nuestro ordenamiento jurídico el carácter preferencial de la simple prueba indiciaria.

\section{EL VALOR DE LA PRUEBA BIOLÓGICA EN LOS PROCESOS DE FILIACIÓN}

\section{a) Concepto y contenido}

Hoy en día, la prueba genética de ADN juega un papel clave en cualquier procedimiento de filiación. Lo anterior se refiere tanto a la reclamación como a la impugnación de una paternidad o maternidad.

\footnotetext{
${ }^{35}$ En relación a una de las demandas de paternidad instadas contra el Monarca, Juan Carlos I de Borbón. Europa Press: «El Constitucional rechaza la demanda de paternidad de Solá contra el rey Juan Carlos». Publicado el 15 de mayo de 2015. http:// www.publico.es/politica/constitucional-rechaza-demanda-paternidad-sola.html.
} 
Anteriormente, los contrastes genéticos entre progenitor e hijo podían realizarse vagamente, únicamente en relación con el grupo sanguí$n^{36}{ }^{36}$. Es evidente que esta prueba no resultaba completamente eficaz. La prueba genética, gracias a los evidentes avances tecnológicos y científicos, ha logrado que sus resultados sean absolutamente reveladores. Tal es el grado de garantía que ya es una realidad que los tribunales de justicia identifican verdad biológica con verdad jurídica ${ }^{37}$. Con independencia de ello, no debemos olvidar que esta prueba no deja de ser una diligencia pericial ${ }^{38} \mathrm{y}$, como tal, tiene la misma naturaleza que cualquier prueba de este tipo. Los artículos 348 y siguientes de la LEC, prevén su regulación. Al ser una pericial científica, es evidente que el juez debe contar con un dictamen facultativo que esclarezca los fines investigados. Esto significa que el juez podrá ajustarse o no a su conclusión final. Ahora bien, para ello deberá motivar suficientemente su fallo, puesto que no puede entenderse lo anterior bajo un puro poder arbitrario ${ }^{39}$. En este aspecto, la Audiencia Provincial de Vizcaya, a través de su sentencia núm. 55/2014, de 6 de mar$\mathrm{zo}^{40}$, señala que «...debe señalarse que no existiendo nomas legales sobre la sana crítica y por tanto hay que atender a criterios lógico racionales, valorando el contenido del dictamen y no específicamente y únicamente su resultado en función de los demás medios de prueba o del objeto del proceso, a fin de dilucidar los hechos controvertidos ${ }^{41}$.

${ }^{36}$ LORENTE LóPEZ, M. C.: La prueba genética y los derechos fundamentales de la persona en los procesos civiles de filiación, paternidad y maternidad, ob. cit., pág. 4.

${ }^{37}$ Ibídem.

${ }^{38}$ Observa ORdóñEz Fernández, C., que hay que tener en cuenta que la última decisión la tendrá el Juez y no el perito. El informe pericial debe facilitar al Juez un medio objetivo para adoptar la decisión. El perito debe poner en conocimiento del Juez las conclusiones genéticas y estadísticas obtenidas, dejando que el Juez valore de forma global el informe con el resto de la prueba y determine su decisión final: En «Pruebas biológicas de paternidad. Estudio crítico de la prueba pericial. Garantías de la prueba y su incidencia en la determinación de la decisión judicial». La Ley, núm. 2, 1995, pág. 995. Respecto a esta cuestión, se pronuncia García Poveda, C., que dice que «la prueba pericial biológica en los procesos de filiación no se regirá por los principios de toda prueba pericial habida cuenta de que el Juez únicamente tendrá conocimiento sobre la admisión o no de la prueba una vez celebrada la vista prevista en este tipo de procedimientos, ya que, a la vista de la prueba practicada en la misma será el momento en que el Juez tendrá elementos de juicio para decidir sobre la admisión o no de las mismas»: En "Las pruebas biológicas en los procesos de filiación. Cómo se soluciona la negativa del sujeto a la práctica de las pruebas de ADN». NJ Bosch, 2003, pág. 2.

${ }^{39}$ Ruiz Moreno, J. M.: El proceso especial de filiación, paternidad y maternidad, ob. cit., pág. 149.

40 (PROV 2014/ 184361).

${ }^{41}$ Esta sentencia, de igual forma, recoge que «La valoración de la prueba pericial debe realizarse teniendo en cuenta los siguientes criterios: a) la prueba de peritos es de libre apreciación, no tasada valorable por el juzgador según su prudente criterio, sin que 
La prueba de ADN funciona con resultados de probabilidad. Su contenido está condicionado en orden a puros porcentajes. En este sentido el Tribunal Supremo ha venido acogiendo «Los predicados verbales de Hummel ${ }^{42}$. Esto significa que, tal y como se recoge en sus sentencias, núm. 855/2004, de 1 de septiembre ${ }^{43}$, y núm. 666/2011, de 4 de octubre ${ }^{44}$, los porcentajes que arroja la prueba de ADN y su probabilidad, son los siguientes:

- Menor del 80\%: no significativo.

— Entre el 80 y el 89,9\%: indicios.

— Entre el 90 y el 94,9\%: probable.

— Entre el 95 y el 98,9\%: muy probable.

— Entre el 99,8 y el 99,9\%: prácticamente probada.

En relación a estas probabilidades ${ }^{45}$, en la citada sentencia núm. 55/2014, de 6 de marzo, de la A. P. de Vizcaya, se refleja como un claro ejemplo de la realidad de muchos procedimientos de reclamación de paternidad, en los que se valora la prueba biológica y da credibilidad a la misma, en defecto de prueba en contrario ${ }^{46}$.

existan reglas preestablecidas que rijan su estimación, por lo que no puede invocarse en casación infracción de precepto alguno en tal sentido. b) Las reglas de la sana crítica no están codificadas, han de ser entendidas como las más elementales directrices de la lógica humana y por ello es extraordinario que pueda revisarse la prueba pericial en casación, sólo impugnarse en el recurso extraordinario la valoración realizada si la misma es contraria en sus conclusiones a la racionalidad o conculca las más elementales directrices de la lógica.

${ }^{42}$ En 1981, K. Hummel describió sus "predicados verbales», que conjugaban distintos intervalos de valores de Probabilidad de Paternidad (W), con sus respectivas interpretaciones, con el objetivo de hacer comprensibles los valores y armonizar las interpretaciones. Consideró que un valor de W igual o superior a 99,73\% ya era suficiente para considerar probado una paternidad desde un punto de vista práctico. Estas interpretaciones han sido aceptadas internacionalmente. De igual forma, nuestra jurisprudencia y nuestro TS (Sentencia de 24 de noviembre de 1992), las admiten como fórmulas válidas: EN ADFTecnoGen, Fundamentos técnicos de las pruebas de $A D N$. http://www.adftecnogen.es/informacion/fundamentos-tecnicos.

43 (RJ 2004, 5470).

44 (RJ 2011, 6699).

45 Con anterioridad a Hummel, Eric Essen-Móller, en 1938, describió una fórmula basándose en el Teorema de Bayes. Esta fórmula servía para calcular la Probabilidad de la Paternidad (W): EN ADFTecnoGen, Fundamentos técnicos de las pruebas de $A D N$. http://www.adftecnogen.es/informacion/fundamentos-tecnicos.

${ }^{46}$ Así recoge literalmente ante un caso de reclamación de paternidad: «(...) el índice de paternidad (que es el valor que indica cuantas veces es mayor la probabilidad del presunto padre, con respecto a un hombre tomado al azar de la población española) es 235.516:1. El valor de Probabilidad de Paternidad obtenido en el presente caso se encuentra en el rango considera por Hummel como «paternidad prácticamente probada, sin que el resultado de dicha prueba pericial haya sido desvirtuado 


\section{b) Efectos de la prueba biológica positiva}

Ante un informe pericial que arroje un resultado de alta Probabilidad de Paternidad, derivado de un análisis de ADN, instado y practicado con ocasión de una acción de filiación, lo lógico es que la demanda sea estimada. A través del dictamen de la correspondiente sentencia en la que se declare la paternidad del demandado (en el caso de que el actor sea el hijo), o del demandante (en el caso de que el actor sea el padre), el efecto inmediato y principal es la rectificación del asiento de filiación que consta en el Registro Civil, en relación con el hijo involucrado en el procedimiento. La sentencia es remitida de oficio por el tribunal de referencia al propio Registro Civil. Es a partir de ese momento cuando se lleva a cabo la rectificación registral de su filiación, adecuándose a su nueva situación. En este aspecto, el artículo 112 CC establece que la filiación produce sus efectos desde que tiene lugar. Su determinación legal tiene efectos retroactivos siempre que sea compatible con la naturaleza de aquéllos y la Ley no dispusiere lo contrario. A su vez, el artículo 113 CC, señala que la filiación se acredita por la inscripción en el Registro Civil, por el documento o sentencia que la determine legalmente, por la presunción de paternidad matrimonial y, a falta de los medios anteriores, por la posesión de estado. Por último, el artículo 114 CC establece que los asientos de la filiación podrán ser rectificados conforme a la Ley del Registro Civil. En conclusión, la nueva determinación legal de filiación que se origina como consecuencia de una sentencia judicial, derivada del resultado de la prueba biológica, va a producir los efectos que integran el contenido básico de la filiación, recogido por la Ley 11/1981, de 13 de mayo:

\section{Derecho de apellidos ${ }^{47}$ :}

La Ley, de 8 de junio, del Registro Civil de $1957^{48}$ (LRC), contempla la regulación relativa al nombre y a los apellidos de la persona en el Título V, Capítulo III, artículos 53 a 62. De igual forma, el Regla-

por prueba propuesta por la parte demandada, la cual no ha aportado informe pericial contradictorio (ni siquiera solicitó la comparecencia de los autores del único dictamen obrante en autos (...)».

${ }^{47}$ Véase LORENTE LóPEZ, M. ${ }^{\text {a }}$ C., que hace un estudio detallado de la consecuencia de la imposición de los apellidos del progenitor determinado por sentencia y en contra de su voluntad: En La prueba genética y los derechos fundamentales de la persona en los procesos civiles de filiación, paternidad y maternidad, ob. cit., pág. 8.

${ }^{48}$ BOE núm. 151, de 10 de junio de 1957. 
mento, de 14 de noviembre de 1958, de la Ley del Registro Civil ${ }^{49}$, trata esta materia en el Título V, Sección V, artículos 192 a 219. Por su parte, el Código Civil recoge en relación con esta materia, los artículos 109 y 111 CC. A su vez, la nueva Ley 20/2011, de 21 de julio, del Registro Civil ${ }^{50}$, regula la atribución del nombre y el derecho a cambio de apellidos en el Título VI, Capítulo I, Sección 2. ${ }^{2}$, artículos 49 a 57 .

En relación a lo anterior, hay que tener en cuenta la redacción que, en su día, la Ley 40/1999, de 5 de noviembre, otorgó al artículo 109 del CC. Con ocasión de aquella, se permitió la facultad del hijo de solicitar la alteración de los apellidos materno y paterno ${ }^{51}$, perdiéndose la histórica prevalencia del apellido paterno. En todo caso, como condición, se imponía la implantación del orden de los apellidos otorgados al mayor de los hermanos. A partir de la LRC de 2011, el artículo 49, refuerza el acuerdo de los progenitores a la hora de decidir el orden de los apellidos del hijo. Se introduce el criterio dirimente, en los casos de desacuerdo o silencio, del Encargado del Registro Civil, en cuya decisión tendrá que tenerse siempre en cuenta el interés del menor.

Esto implica que, la nueva filiación derivada de una sentencia de paternidad, implica el cambio de apellidos del hijo con el fin de adecuarlo a su nueva realidad. Sin embargo, entendiendo a la complicación que esto puede originar en relación con la identificación habitual y conocida de la persona afectada, ya el artículo 59.3 LRC de 1957, y el artículo 209.3 del RRC de 1958, contemplaban la posibilidad de renunciar a este cambio de apellidos, instando el expediente de conservación de los habituales ante el Registro Civil. El plazo para instar tal expediente quedaba fijado en los dos meses siguientes a la inscripción de la nueva filiación. La LRC de 2011, mantiene y simplifica este trámite, estableciendo que, en el mismo plazo de dos meses desde la inscripción, la solicitud de conservación de apellidos habituales se podrá realizar a través de declaración de voluntad del afectado. Así lo recoge en el artículo 53.5. Esto, en realidad, debe entenderse como un derecho del hijo a renunciar a los apellidos de su ya declarado padre. En el Registro Civil constará determinada la filiación legal entre padre e hijo, pero ambos llevaran apellidos distintos.

${ }^{49}$ BOE núm. 296, de 11 de diciembre de 1958.

${ }^{50}$ BOE núm. 175, de 22 de julio de 2011.

${ }^{51}$ LinACERo DE LA FuENTE, M. «Derecho a la identidad personal: el nombre y los apellidos», en Derecho Civil IV. Introducción al Derecho Civil, Tirant lo Blanch, Valencia, 2013, pág. 439. 
En el caso de que se trate de un hijo menor de edad, en el que la maternidad ya estaba legalmente determinada y el niño tenía atribuido los apellidos maternos, se aplicarán reglas generales del orden del apellido paterno y materno. En el caso de discrepancia entre los padres sobre esta cuestión, decidirá el Encargado del Registro Civil, siempre atendiendo al interés del menor. Ante el desacuerdo con su decisión, la problemática podrá terminar en los tribunales de justicia. A modo de ejemplo, citamos la reciente sentencia del TS. núm. $76 / 2015$, de 17 de febrero ${ }^{52}$, por medio de la que se resuelve esta cuestión en un caso relativo a determinación de la filiación, guarda, custodia y alimentos, así como del orden de apellidos de un menor tras la sentencia que rectificaba su asiento registral ${ }^{53}$. Está claro que, tal y como aplicó el TS. en este supuesto, en estos casos hay que tener siempre en cuenta el interés superior del menor, así como los elementos integradores de su personalidad.

\section{Derecho de alimentos:}

El padre y la madre, aunque no ostenten la patria potestad, estarán obligados a velar por los hijos menores y a prestarles alimentos ${ }^{54}$.

52 (RJ 2015, 924).

${ }^{53} \mathrm{La}$ Sala dejaba constancia en esta resolución de lo siguiente:

"(...) existe un nacimiento de una sola filiación determinando ésta los apellidos, y a consecuencia de un reconocimiento tardio en el inicio del procedimiento judicial, al que se suma el de duración de éste, el cambio del orden de los apellidos alcanza al menor a una edad en que tanto la vida social como en la escolar es conocido por el primer apellido en su día determinado». La sentencia tiene en cuenta las siguientes circunstancias:

"1. Debe subrayarse que las normas registrales del orden de apellidos están dirigidas al momento anterior a la inscripción registral de nacimiento, concediendo a los padres una opción que ha de ejercitarse "antes de la inscripción" y, de no realizarse, se aplica el orden supletorio establecido reglamentariamente.

2. En el caso de la determinación judicial de la paternidad, la filiación se establece de forma sobrevenida, con las consecuencias inherentes a los apellidos y entra en juego el derecho del menor a su nombre, puesto que en el periodo transcurrido entre el nacimiento y el momento en que se puso fin al proceso por sentencia firme había venido utilizando el primer apellido materno, siendo patente la relevancia individualizadora del primero de los apellidos de una persona.

3. El menor en el momento de iniciarse el proceso estaba escolarizado y había venido utilizando el primer apellido de su madre desde su nacimiento, sin que hubiera tenido relación personal estable con su padre. En estas circunstancias es identificable el interés del menor en seguir manteniendo su nombre y, en este caso, su primer apellido materno, al ser conocido por el mismo en los diferentes ámbitos familiar, social o escolar.»

${ }^{54}$ DurÁn Rivacoba, R., opina que hay que tener en cuenta que el nacimiento de un hijo, independientemente del «común alborozo» que la nueva criatura provoca, produce también consecuencias que obedecen a la naturaleza de las cosas, una vertiente 
Así se recoge en el artículo 110 CC. En relación con los procedimientos de filiación, cuando esta haya sido determinada a través de sentencia judicial contra la expresa oposición del progenitor, éste quedará excluido de la patria potestad, en relación con las funciones tuitivas, y no ostentará derechos por Ministerio de la Ley respecto al hijo, sus descendientes, así como respecto a sus herencias. Independientemente de lo anterior, el progenitor determinado quedará obligado a prestarle alimentos. Así se señala en el artículo 111 CC.

\section{Derechos sucesorios:}

En aplicación del citado artículo 111 CC, el progenitor legalmente determinado contra su expresa oposición, no tendrá derechos respecto a la herencia del hijo. Esto se encuentra dentro de la llamada "pérdida de derechos sucesorios». A este respecto, el artículo 807 CC, recoge que los hijos son herederos forzosos de sus padres en las sucesiones testadas y, de igual forma, serán los primeros llamados como herederos legales en el caso de que la sucesión sea ab intestato, o legal, sin concurrencia de testamento. Respecto a lo anterior, el artículo $931 \mathrm{CC}$, determina que lo anterior se impondrá sin distinción de sexo, edad o filiación. Esto significa que el padre quedará privado de los derechos de la herencia de su hijo, pero no a la inversa. Con todo, está previsto legalmente, que esa sanción pueda ser levantada por el representante legal del hijo, aprobada judicialmente, o por voluntad del propio hijo, una vez alcanzada la plena capacidad ${ }^{55}$.

\section{c) La negativa del demandado a someterse a la prueba biológica}

En la práctica judicial no es infrecuente encontrarnos ante supuestos en los que, ante la petición de prueba pericial biológica, el demandado rechaza o se niega a someterse a la misma. Esta situación provoca la limitación del ejercicio de los derechos del hijo en la búsqueda de su verdad genética. Es este respecto, el TS ya ha declarado de forma reiterada que, para la investigación de la paternidad, se admiten dos clases de prueba ${ }^{56}$ : la directa (biológica y de reconocimien-

mínima que garantiza el Derecho, como es la provisión de alimentos necesarios para subsistir o que los derechos sucesorios eventuales no se vean omitidos: en El anonimato del progenitor, ob. cit., pág. 1 .

${ }^{55}$ Díez-Picazo, L., Gullón Ballesteros, A.: Sistema de Derecho Civil: Derecho de Familia y Derecho de Sucesiones, ob. cit., pág. 310.

${ }^{56}$ Véase SAP de Madrid, de 17 de septiembre de 1999 (AC 1999, 1828). 
to), y las indirectas o presuntivas. Entre estas últimas es donde se encuadra la negativa a someterse voluntariamente a la prueba biológica. El artículo 767.4 LEC marca que «La negativa injustificada a someterse a la prueba biológica de paternidad o maternidad permitirá al tribunal declarar la filiación reclamada, siempre que existan indicios de esa paternidad o maternidad y la prueba de ésta no se haya obtenido por otros medios». Esto significa que la simple negativa no tiene directamente un valor de ficta confessio ${ }^{57}$ sino que, junto a este dato, debe estar presente algún indicio de paternidad o maternidad. La negativa a someterse a la prueba será valorada por el tribunal como un indicio pero, junto a este, debe existir algún dato acreditativo de la «oportunidad» de relación sexual en la época de la concepción del hijo ${ }^{58}$. La presencia de todo lo anterior, ya podrá llevar aparejado el convencimiento del juzgador sobre la realidad que se pretende acreditar. En conclusión, la negativa injustificada a someterse a la prueba tendrá que ser valorada en contra del supuesto progenitor ${ }^{59}$.

La pregunta determinante en esta cuestión es, ¿qué motivos pueden ser considerados como justificados para negarse a someterse a la prueba biológica? La doctrina ha descartado como razón justificada la que tenga su origen en motivos religiosos o de conciencia. De igual forma, no se puede alegar como causa justificada la falta de credibilidad o confianza en los resultados que pueda arrojar la misma, o su procedimiento de desarrollo. Por último, no pueden alegarse la imposibilidad física de acudir a la celebración de su práctica, o los motivos basados en la llamada exceptio plurium concubentium, consistente en la posibilidad de que la madre hubiera mantenido relaciones sexuales con más de un hombre en la época de la concepción. Este hecho podrá ser valorado como prueba, pero no descarta automáticamente que la acción triunfe puesto que restan otros medios de prueba, biológicos, o de otra índole.

Con independencia de lo anterior, existen otros motivos que merecen distinta valoración. Nos referimos a los supuestos en los que el demandado alegue como justificación un atentado a su honor o su intimidad. A este respecto, ha sido decisiva la argumentación esgrimida por el Tribunal Constitucional (TC) que concluye con que «en los

${ }^{57} \mathrm{El}$ art. 304 LEC señala que «Si la parte citada para el interrogatorio no compareciere al juicio, el tribunal podrá considerar reconocidos como ciertos los hechos en que dicha parte hubiese intervenido personalmente y cuya fijación como ciertos le sea enteramente perjudicial (...)».

${ }^{58}$ SSTS, de 23 de septiembre de 1988 (RJ 1988, 6855) y de 18 de mayo de 1990 (RJ 1990, 3740).

${ }^{59}$ SAP de Cuidad Real núm. 88/2014, de 22 de abril (PROV 2014, 163172). 
supuestos de filiación, prevalece el interés social y de orden público que subyace en las declaraciones de filiación ${ }^{60}$. Esto significa que la supuesta vulneración de derechos fundamentales del artículo 18.1 CE, no es razón suficiente para la negativa ${ }^{61}$. Ante estos supuestos, el tribunal, por tanto, podrá considerar la negativa como un indicio de paternidad $^{62}$. En el caso de que la negativa esté fundada en la vulneración del derecho a la intimidad del demandado, la jurisprudencia ${ }^{63}$ ha entendido que el sometimiento a la prueba supone un sacrificio nimio de ese derecho que permite desarrollar otro derecho de la personalidad, no menos relevante, como es el derecho del menor a conocer su origen biológico y, de igual forma, que los progenitores asuman sus obligaciones legales de alimentos, formación, etc.

En este sentido, el $\mathrm{TC}^{64}$, constriñe a causa justificada para no someterse a la prueba biológica las hipótesis consistente en «quebranto

${ }^{60}$ STC núm. 7/1994, de 17 de enero (RTC 1994, 7) y STC núm. 177/2007, de 23 de julio (RTC 2007, 177). Entre los autores que han comentado esta sentencia, se encuentran RUBIDO DE LA TORRE, C.: «La investigación de la paternidad en el derecho vigente. La prueba biológica y las consecuencias de su negativa». $R G D$, 1995, pág. 4847; BuJOSA VADELL, L.: «El alcance de la obligación de sometimiento a las pruebas biológicas en los procesos de filiación (en torno a la STC 7/1994, de 17 de enero)». $R G D, 1996$, pág. 179; Moro Almaraz, M. J.: "Comentario a la sentencia del Tribunal Constitucional 7/1994, de 17 de enero». CCJC, núm. 34, 1994, pág. 325.

${ }^{61}$ Como advierte la STS, de 25 de abril de 1991 (seguida entre otras por la de 29 de marzo y 8 de octubre de 1993), la realización de las pruebas biológicas y antropomórficas conforme al (antiguo) art. 127 CC, cuya justificación ético-social ha de buscarse en el carácter prioritario y fundamental que es el derecho de toda persona a determinar su origen biológico, con independencia de la clase de filiación, encuentra su práctica ante los Tribunales oposiciones y reticencias que tratan de buscar amparo legal en preceptos constitucionales, como son el art. 15 (derecho a la vida e integridad), art. 18 (derecho a la intimidad), y art. 20.4. Pues bien, ante esto, nuestro TS tienen establecido con reiteración la prevalencia de toda persona a determinar su origen biológico sobre los supuestos derechos a la vida e integridad física, o la intimidad. La cuestión se circunscribe a dilucidar cuál de los derechos que pueden verse afectados en el conflicto ha de prevalecer como prioritario, si el de la investigación de la paternidad o el derecho al honor o a la intimidad personal o familiar; debiéndose decir, a este respecto, que no puede considerarse que la investigación de la paternidad tenga un fin injurioso o difamatorio, aunque obviamente pueda suponer molestias en la intimidad familiar de las personas, más dicho derecho a conocer el propio origen, como emanación de la dignidad humana, es indudablemente un derecho de la personalidad inviolable que se encuadra en el art. $10 \mathrm{CE}$ y alcanza el rango de derecho fundamental de la persona, no siendo legítimo, por tanto, a otros seres humanos privar al sujeto de ese conocimiento de su origen y de su verdadera filiación. En conclusión, ha de prevalecer el interés social y de orden público que subyace en la investigación de la paternidad.

${ }^{62}$ Cordero Cutillas, I.: «La impugnación de la paternidad matrimonial». Colección de Estudios Jurídicos de la Universidad Jaime I, núm. 6, Castellón, 2001, pág. 92.

${ }^{63}$ SAP de Las Palmas núm. 381/2013, de 8 de julio (PROV 2013, 318838).

${ }^{64}$ STC 7/1994, de 17 de enero (RTC 1994, 7). 
gravísimo para la salud o no existencia de indicios serios de la conducta que se atribuye al demandado» ${ }^{65}$. Entendemos que la primera de esas hipótesis resulta de carácter absolutamente excepcional puesto que, hoy en día, la prueba biológica no produce ningún riesgo ni agresión a la persona desde el momento en que se obtiene con una pequeña muestra saliva. Ni siquiera es necesaria extracción alguna de muestra de sangre. En cuanto a la segunda de las hipótesis, se entiende que no cualquier obstrucción del demandado será relevante en miras a provocar la determinación de la filiación ${ }^{66}$. Únicamente, cuando esa negativa lleve implícito un ánimo caprichoso e injustificado podrá entenderse su carácter de indicio valioso o muy cualificado.

La vinculación del afectado a la práctica de la prueba biológica no constituye propiamente un deber sino, una carga procesal ${ }^{67}$. Su incumplimiento no puede dar lugar a imponer su realización mediante medios coactivos ${ }^{68}$, sino que, únicamente, determina que, en caso de ser justificada, recaigan sobre la persona renuente las consecuencias de la falta de prueba, siempre que concurran los requisitos

${ }^{65}$ SAP de Cuenca núm. 161/2009, de 30 de junio de 2009.

${ }^{66}$ Ruiz Moreno, J. M.: El proceso especial de filiación, paternidad y maternidad, ob. cit., pág. 158 .

${ }^{67}$ Como observa EtXeberRía Guridi, J. F., a través de la sentencia del TC núm. 95/1999, de 31 de mayo, se consolidó el definitivo abandono de la pretensión de atribuir a la negativa de afectado por la prueba de ADN, el carácter de obligación procesal, con las consecuencias que ello podría acarrear: En «La negativa al sometimiento a las pruebas biológicas de filiación y la STC 95/1999, de 31 de mayo, ¿una renuncia a postulados anteriores?». $A C, 2000$, núm. 1, pág. 485.

${ }^{68}$ Se plantea Quesada GonZÁlez, M. ${ }^{a}$, C., en relación con la posible imposición forzosa del sometimiento al análisis de ADN en los procesos de filiación, permitida, por ejemplo, en Alemania, que podría imponerse siempre que se hiciera de una forma comedida y cumpliendo con determinados requisitos. La autora, estima conveniente su imposición forzosa en protección del interés el menor. Establece que podría resultar más efectivo que la imposición de multas o delitos de desobediencia. De igual forma, entiende que para lograr dicho fin, debería siempre ser regulado a través de una Ley Orgánica, observándose los principios de proporcionalidad y de necesidad («debería prever la duración de la privación de libertad, limitándose al estrictamente necesario para la toma de muestras»), siempre que esa prueba resultase indispensable para el esclarecimiento de los hechos que se tratan en el supuesto. Asemeja la imposición a otras figuras coercitivas como los casos en que se detiene a una persona contra su voluntad, cuando se embarga una propiedad, o se desahucia a alguien de su vivienda: En La prueba de ADN en los procesos de filiación, ob. cit., pág. 582. De igual forma, apoyando esta postura, se pronuncia BUJOSA VADELL, L., quien manifiesta que «sería necesario una nueva norma habilitante con rango de ley orgánica, que fijara los criterios de proporcionalidad y permitiera la lícita coacción de esta prueba». El autor cree que esta norma no sería inconstitucional si respetara ese principio de proporcionalidad en el caso concreto: En El alcance de la obligación de sometimiento a las pruebas biológicas en los procesos de filiación (en torno a la STC 7/1994, de 17 de enero), ob. cit., pág. 192. 
determinados por la doctrina constitucional y jurisprudencia civil: indicios suficientes para conjuntamente con la consideración de dicha negativa como indicio muy cualificado, consideren determinada presuntivamente la paternidad reclamada ${ }^{69}$. Esto significa que, ante demandas en las que no exista ningún tipo de indicio de relación efectiva entre las partes o, se entienda que existen en el transfondo otros intereses insolidarios, se podrá desestimar la demanda denegando, incluso, la práctica de la prueba biológica solicitada o, habiéndose acordado por el tribunal, que el demandado se niegue a someterse por entender que de la propia demanda o hechos narrados no hay indicio, seriedad o posibilidad de filiación biológica entre el demandado y el hijo.

Un ejemplo práctico que pone en duda la pertinencia de la norma anterior, ha sido precisamente uno de los dos asuntos seguidos contra la persona anteriormente mencionada (dada su importancia institucional). Lo que se aplicó en este segundo caso tuvo una innegable repercusión pública en España ${ }^{70}$. El TS, en un principio admitió la demanda de filiación, junto a la que se acompañaba un acta declaración notarial firmada por la madre de la demandante, mujer con la que el demandado supuestamente había mantenido una relación afectiva en el pasado. Esta aseguraba que era el padre de su hija. La parte demandada recurrió esa admisión y, solo dos meses después, el Tribunal, en fecha 11 de marzo de 2015, acogió el recurso y rechazó la admisión de la demanda a través del oportuno Auto $^{71}$. Para tomar esa decisión, se fundó en que el demandado había aportado datos relacionados con intervenciones en prensa y demás medios de comunicación que había realizado la demandante y en las que se contradecía con lo narrado en el acta notarial en el que previamente se basó el Tribunal para admitir la demanda. Todo esto se produjo a pesar de que la demandante había instado y ofrecido en la demanda la práctica de la pericial biológica. En este caso, ni siquiera fue necesario valorar una negativa a someterse a la prueba de ADN. Directamente, no se dio lugar a su práctica al inadmitirse la demanda.

${ }^{69}$ SSTS de 7 de septiembre de 2005, y de 2 de febrero de 2006.

${ }^{70}$ Se trata de la segunda demanda de paternidad presentada por una ciudadana belga contra el Monarca, Juan Carlos I de Borbón. La demanda, aunque previamente fue admitida, finalmente fue rechazada en aras del recurso de reposición interpuesto por el demandado, y admitido a través del Auto de 11 de marzo del TS: En Rincón, R: «El Supremo ve "frívola" la demanda de paternidad contra Juan Carlos I». El País. Publicado el 9 de abril de 2015. http://politica.elpais.com/politica/2015/04/09/actualidad/1428578974_886700.html.

${ }^{71}$ Auto del TS, de 11 de marzo de 2015 (Sala Primera). 
A lo anterior, debemos decir que el TS alegó literalmente que la demanda "carece por completo de verosimilitud o seriedad» y es «lisa y llanamente falsa, frívola y torcidera». Siete magistrados frente a tres, se mostraron en contra de la admisión de la demanda y tuvieron en cuenta esas declaraciones que, con posterioridad a la admisión de la misma, la demandante realizó a varios medios de comunicación. Entre las contradicciones alegadas se encontraba el dato relativo al modo en que supuestamente se conocieron las partes implicadas o, del momento en que la hija fue informada de la identidad de su padre. Contra el Auto de archivo se presentó voto particular por parte de dos magistrados ${ }^{72}$. Manifestaron su rechazo a la inadmisión de la demanda por entender que era la primera vez que la Sala Primera del TS dejaba sin efecto la decisión de admitir a trámite una demanda de paternidad previamente admitida, y con las mismas pruebas con las que se aceptó. Entendieron que no se había valorado correctamente el principio de prueba y que el recurso de reposición interpuesto por el demandado contra la demanda, no constituía un "medio apto» para posibilitar una valoración de pruebas aportadas o practicadas después de haberse dictado la resolución recurrida.

En conclusión, el ordenamiento jurídico español valora como un indicio valioso y muy cualificado la negativa del demandado a someterse a la prueba biológica. No cualquier causa caprichosa exonera al demandado de dispensarle la práctica de la misma. Nuestra jurisprudencia acepta únicamente causas que produzcan un perjuicio físico en la integridad a la persona afectada, o que no haya en el procedimiento ningún dato serio que arroje la sospecha de que hay veracidad en los hechos pretendidos en los que se justifica la demanda. Independientemente de lo anterior, este indicio de negativa infundada al sometimiento debe ir acompañado de otros datos que arrojen la posibilidad de relación sexual entre los intervinientes en la época de la concepción del pretendido hijo. Ahora bien, teniendo en cuenta que la prueba de ADN arroja prácticamente la verdad material y biológica, entendemos que, tal y como hemos defendido, lo conveniente sería que siempre que se solicite la realización de la misma, la demanda deba ser admitida a trámite tal y como sucede con cualquier otra que cumple con los requisitos formales y procesales en el ámbito civil.

De igual forma, defendemos que lo apropiado debe ser que, siempre que se solicite su práctica, el tribunal imperativamente deba acordarla, con independencia de que de los hechos

${ }^{72}$ Magistrados, Sres. Ferrándiz y O’Callaghan. 
alegados por el peticionario no sean reveladores. Para ello, proponemos, una vez más, la modificación del art. 767 LEC, en el sentido de que contemple de forma expresa esta premisa. Decimos esto por el nimio sacrificio que para cualquier persona resulta el sometimiento a la misma y, al tiempo, la gran veracidad que arroja su resultado. Con esto se respetaría absolutamente el derecho a investigar y a conocer la paternidad que protege el artículo 39.2 CE.

Dejando asentado lo anterior, otro de los problemas que se presentan en relación con la prueba biológica, descansa en los casos en que, ante la interposición de la acción de reclamación de filiación por parte del supuesto padre, la madre demandada se niega a colaborar y a llevar al menor a la toma de muestra de saliva. El contraste de muestras es necesario para obtener la prueba directa. La negativa a someter al menor ${ }^{73}$ a esta prueba, cuando la razón alegada es entender que puede ser perjudicial para el niño, debe ser rechazada. Esta prueba, como ya hemos indicado, no presenta sacrificio físico o psíquico alguno para el menor. Los tribunales españoles en estos casos, están aplicando la valoración del indicio de la negativa, de igual forma que cuando el que se opone a su realización es una persona mayor de edad $^{74}$.

Por último, ante esos casos en los que es el supuesto padre el que pretende que se determine legalmente la filiación de un hijo a su favor, es evidente que estamos ante un dato revelador. El hecho de que una persona libremente pretenda conseguir que se constate oficialmente una situación que le va a generar consecuencias económicas importantes debe ser valorado como una presunción de veracidad. Como decimos, es poco probable que un hombre, si no lo cree realmente, decida reclamar una paternidad de un hijo que inevitablemente le va a generar una serie de obligaciones perpetuas, la mayor parte de tipo alimenticio y económico. Los tribunales españoles valoran positivamente este tipo de situaciones pero, no más allá que en cualquier asunto de filiación.

${ }^{73}$ Entre los autores que consideran procedente el nombramiento de un defensor judicial al menor en los procesos de filiación, cuando los intereses de éste no coinciden con los de su representante legal, se encuentran MAYOR DEL HoYO, M. ${ }^{\mathrm{a}} \mathrm{V}$ : «Sobre la intervención del defensor judicial en los procesos de impugnación de la paternidad (comentario a la STS 481/1997, de 5 de junio)». ADC, 1998, pág. 924; MORENO MARTíNEZ, J. A.: "Comentario a la sentencia del TS de 5 de junio de 1997». CCJC, núm. 45, 1997, pág. 1098, y CARBAJO GonZÁLEZ, J.: «Las acciones de impugnación de la filiación en la jurisprudencia (a propósito de la sentencia del TS de 5 de junio de 1997)». AC, doctrina VIII, 2000, pág. 175.

${ }^{74}$ STS núm. 589/2004, de 17 de junio (RJ 2004, 3618). 


\section{LAS ACCIONES DE FILIACIÓN EN EL SISTEMA JURÍDICO ESPAÑOL}

En relación con los tipos de acciones de filiación, ya hemos señalado anteriormente que pueden ser de tres tipos: reclamación, impugnación y mixta. En nuestro ordenamiento hay que tener cuenta una serie de datos para iniciar el procedimiento de filiación. Por una parte, habrá de distinguir entre las filiaciones matrimoniales y las no matrimoniales y, a su vez, en ambos casos, habrá de valorarse si entre hijo y progenitor medió posesión de estado o no. Lo anterior es determinante a efectos de legitimación, así como del plazo preclusivo que el accionante tiene para ejercer su derecho.

La disciplina de la regulación de estas acciones de filiación, debido a su carácter incompleto y contradictorio, necesita el uso de herramientas interpretativas ${ }^{75}$. En torno a estas acciones de filiación descansan razones de interés general así como de orden imperativo de las mismas. De igual forma, hay que destacar la indisponibilidad de la materia para las partes procesales, que quedará sujeta a controles públicos. Téngase en cuenta que, según deriva del artículo 751.1 LEC, en los procesos de filiación no producen efectos el allanamiento del demandado, ni la renuncia a la acción o la transacción de las partes, por lo que pudiera ser discutible que se pudiera otorgar a actos anteriores de carácter extraprocesal, el valor de conducta jurídicamente vinculante $^{76}$. En este aspecto la sentencia del Tribunal Supremo, de 12 de enero de $2015^{77}$, da por hecho lo anterior al afirmar que los actos propios de las partes no pueden transcender con la eficacia pretendida a la acción de filiación al ser indisponible.

Hay que recordar que el modelo de filiación que se incorporó con ocasión de la Ley 11/1981, de 13 de mayo, supuso una rotunda oposición al régimen anterior el cual protegía de una forma desmesurada a la familia matrimonial, calificándose la no matrimonial de «ilegítima ${ }^{78}$. La desigualdad y las restricciones legislativas eran los puntos protagonistas de la filiación de la codificación. Durante décadas esa normativa no fue reflejo de la realidad de la sociedad. En consecuencia, en las sucesivas reformas, el sistema fue encaminándo-

${ }^{75}$ García Vicente, J. R: Los principios de las acciones de filiación. Aranzadi, Pamplona, 2004, pág. 2.

${ }^{76}$ Díaz Martínez, A.: "Buena fe, retraso desleal y actos propios en el ejercicio de las acciones de filiación». Aranzadi, Civil-Mercantil, núm. 4/2015, Parte Comentario, 2015, pág. 1.

77 (RJ 2015, 610).

${ }^{78}$ García Vicente, J. R.: Los principios de las acciones de filiación, ob. cit., pág. 2. 
se a mitigar esos intolerables efectos. La sociedad española experimentó una gran reforma como resultado de grandes experiencias sociales y políticas. En esa década se implantó nuestro sistema constitucional y, entre sus exigencias constitucionales, se encontraban, entre otros, el principio de igualdad, la promoción de la dignidad de la persona, la protección concreta del menor, la tutela de la familia sin considerar su origen y la investigación de la paternidad. Escasos años después se dictó la Ley del divorcio. En este nuevo modelo, el interés del hijo se vio protegido en varias dimensiones: El interés en su protección y en su estabilidad social propició en ocasiones el sacrificio de la verdad biológica. Ejemplo de ello resultó ser la aceptación del reconocimiento de complacencia que se introdujo dentro de las acciones de filiación ${ }^{79}$.

Dicho lo anterior, vamos a hacer referencia a una de las cuestiones más polémicas de nuestro sistema de acciones de filiación: la «titularidad» del derecho a conocer el propio origen. Se discute si ese derecho se otorga sólo a los hijos, o de igual forma, también a los progenitores.

1. Las acciones de reclamación de filiación:

Es una realidad que el derecho relativo a la materia de filiación no juega en nuestro derecho en términos absolutos. De lo contrario, carecería de sentido ${ }^{80}$ el establecimiento de plazos de caducidad en el ejercicio de las acciones o las restricciones a la legitimación activa. Ambas cuestiones están claramente respaldadas por el Tribunal Constitucional. Junto al invocado principio de la verdad biológica, el legislador, a la hora de normar en materia de filiación, ha valorado de igual forma principios de seguridad jurídica como el mantenimiento de la paz familiar, el interés del menor o la necesidad de un principio de prueba junto a la demanda de filiación. Como expresa Quicios Molina: «verdad biológica sí, pero siempre que detrás haya un interés digno de protección, no verdad biológica porque sí» ${ }^{81}$.

${ }^{79}$ No hay duda que estos reconocimientos de complacencia pueden servir como mecanismo para que muchas personas huyan de la necesidad de pasar por un proceso de adopción, simplificando los trámites de la determinación legal de la filiación. Ibídem, pág. 7.

${ }^{80}$ DíAz MARTínez, A.: Buena fe, retraso desleal y actos propios en el ejercicio de las acciones de filiación, ob. cit., pág. 1.

${ }^{81}$ Quicios Molina, S.: «Determinación e impugnación de la filiación». Cuadernos Aranzadi Civil-Mercantil, 2014, pág. 33. 
El artículo $131 \mathrm{CC}$ establece que «Cualquier persona con interés legítimo tiene acción para que se declare la filiación manifestada por la constante posesión de estado. Se exceptúa el supuesto de que la filiación que se reclama contradiga otra legalmente determinada». Con estas acciones se pretende obtener un pronunciamiento judicial que determine la filiación de una persona, bien porque anteriormente no tenía ninguna, o porque se pretende una rectificación registral de la ya determinada. Como vemos, la legitimación activa de estas acciones se hace depender de la posesión de estado la cual, tal y como se ha indicado $^{82}$, se refiere a una determinada situación de apariencia. A través de una serie de actos concluyentes se crea entre padre e hijos una apariencia jurídica que sirve para declarar la realidad que refleja. La jurisprudencia ha hecho referencia a estos actos de apariencia exigiendo una serie de requisitos:

- Nomen: Consiste en el hecho de llevar el apellido de otra.

- Tractatus: Se refiere a la forma que una persona tiene de tratar a otra, coincidiendo con lo usual de las relaciones entre padres e hijos.

- Fama: Opinión general que reconoce a un persona como hijo de un determinado padre.

La reforma del año 1981 exigió que, para alegar esa posesión de estado como fondo de una acción de reclamación de filiación, esa situación fuera continua y no interrumpida. En este artículo $131 \mathrm{CC}$, como vemos, se contempla una amplísima legitimación para interponer la acción, no matizando que se entiende por interés legítimo. Es evidente que este interrogante deberá ser interpretado por el tribunal correspondiente. Al tiempo, el artículo 132, relativo a la filiación matrimonial, sin posesión de estado, señala que, «cuando falte la correspondiente posesión de estado, la acción de reclamación de filiación matrimonial, que es imprescriptible, corresponde al padre, a la madre o al hijo».

El polémico artículo 133 CC, en su redacción anterior, se limitaba a recoger que la acción de filiación no matrimonial, sin posesión de estado, corresponde al hijo durante toda la vida. Respecto a este precepto hay que indicar que fueron muchas las voces que se alzaron en contra de su discriminatorio contenido, en relación con el progenitor. La razón de peso de esas críticas descansaba en que no había

${ }^{82}$ Díez-Picazo, L., Gullón Ballesteros, A.: Sistema de Derecho Civil: Derecho de Familia y Derecho de Sucesiones, ob. cit., pág. 227. 
razón justificada ${ }^{83}$ para atribuir legitimación al progenitor si la filiación era matrimonial, y restringirla en el caso de la no matrimonial. Esta situación quebrantaba claramente el principio de igualdad, dependiendo de si la filiación era matrimonial o no matrimonial. En respuesta a lo anterior, el TC, a través de la sentencia núm. 273/2005, de 27 de octubre ${ }^{84}$, declaró inconstitucional este párrafo. Este criterio jurisprudencial ha alcanzado finalmente rango de ley con ocasión de la entrada en vigor de la Ley 26/2015, de 28 de julio, de Modificación del Sistema de Protección a la Infancia y a la Adolescencia ${ }^{85}$. De esta forma, el artículo contempla ahora un segundo párrafo en el que ya se reconoce esta acción de filiación a los progenitores. La diferencia está en que, mientras al hijo se le concede toda su vida para accionar, al progenitor que quiera reclamar la filiación de un hijo, no matrimonial y sin posesión de estado, se le limita a un plazo de un año desde que hubiera tenido conocimiento de los hechos en que basa su pretensión. En este caso, el legislador otorga legitimación a los herederos en el caso de que el hijo falleciera antes de transcurrir cuatro años desde que alcanzase la plena capacidad, o durante el año siguiente al descubrimiento de las pruebas en que haya de fundar su demanda. A estos les otorga el tiempo que resta hasta cumplir dichos plazos.

La cuestión a debatir en cuanto al derecho a conocer los orígenes biológicos del hijo puede situarse en la limitación del plazo de ejercicio de la acción. Como vemos, en el caso de la filiación matrimonial sin posesión de estado, el plazo no es un inconveniente para la búsqueda de los orígenes, puesto que se le otorga el carácter de imprescriptible. Esto significa que el hijo tendrá toda su vida para poder ejercitar ese derecho. De igual forma, ante la falta de posesión de estado, en los casos de filiación no matrimonial ocurre lo mismo. Esto significa que el derecho a conocer los orígenes biológicos en los casos de filiación natural está ampliamente protegido por la Ley al otorgar-

${ }^{83}$ GaRcía Vicente, J. R.: Los principios de las acciones de filiación, ob. cit., pág. 13.

${ }^{84}$ Suplemento del BOE núm. 285, de 29 de noviembre de 2005.

${ }^{85}$ La nueva redacción del art. 133, una vez modificado por la Ley 26/2015, de 28 de julio, queda de la siguiente forma: «1. La acción de reclamación de filiación no matrimonial, cuando falte la respectiva posesión de estado, corresponderá al hijo durante toda su vida. Si el hijo falleciera antes de transcurrir cuatro años desde que alcanzare la mayoría de edad o recobrare la capacidad suficiente a tales efectos, o durante el año siguiente al descubrimiento de las pruebas en que se funde la demanda, su acción corresponderá a sus herederos por el tiempo que faltare para completar dichos plazos. 2. Igualmente podrán ejercitar la presente acción de filiación los progenitores en un plazo contado desde que hubieran tenido conocimiento de los hechos en que hayan de basar su reclamación. Esta acción no será transmisible a los herederos quiénes solo podrán continuar la acción que el progenitor hubiere iniciado en vida». 
le el derecho de por vida. Lo anterior ha sido refrendado por las sentencias del TS de fecha 11 y 12 de abril de $2012^{86}$, así como en la de 3 de diciembre de 2014. A través de estas resoluciones se recoge que no se puede apreciar abuso de derecho o fraude de ley cuando el hijo ejercita tardíamente la acción de reclamación de filiación, aunque sea muchos años después de conocer su origen biológico, ni cuando lo hace el progenitor que sabía de su condición mucho tiempo antes de la interposición de la demanda. Lo anterior resultaría contrario a los principios protegidos en el ordenamiento jurídico que protege la dignidad de la persona ${ }^{87}$. Es más, por lo que respecta a la interposición de la acción de reclamación por parte del hijo, el TS ha descartado la valoración de una posible vileza del móvil, generalmente económico, por el que el hijo decide accionar ante los tribunales. En la reciente sentencia del TS, de 12 de enero de $2015^{88}$, el Tribunal consideró que, ni el mantenimiento de un falso estado civil de forma intencionada por parte del hijo, quien conocía el dato de su verdadero progenitor desde años atrás, podía afectar a la interposición retardada con fines sucesorios de las acciones de impugnación y de reclamación de filiación.

En el caso de que el ejercicio tardío de la acción de reclamación de filiación sea achacable al padre, aún sin negar que, en virtud de lo anteriormente explicado, la demanda haya de prosperar si se prueba la relación biológica, el TS ha aceptado limitar los efectos de la filiación, aunque evidentemente sea declarada. Así se refleja a través de la sentencia del TS, de 17 de febrero de $2015^{89}$, en la que, en contra de la interpretación literal del artículo 109 CC, se resuelve protegiendo el interés superior del menor y su derecho al nombre y a su propia imagen. El hijo, a pesar de pasar a llevar el apellido del nuevo padre en segundo lugar, continuaría usando de primero el materno, el cual ve-

86 (RJ 2012, 5745), (RJ 2012, 5898), (RJ 2014, 6258).

${ }^{87}$ A pesar de ello, en el caso de la sentencia del TS, de 11 de abril de 2012, el Tribunal deja abierta la posibilidad de apreciar fraude de ley en el ejercicio de la acción de reclamación de filiación, si se identifica cumplidamente tanto la norma defraudada como el resultado contrario que se produciría en el ordenamiento jurídico.

88 (RJ 2015, 610).

${ }^{89}$ En este supuesto, a pesar de resultar acreditado que la hija tenía un claro conocimiento de su verdadera filiación materna, desde varios años antes del fallecimiento de su madre legal-registral, a la cual sucedió y en consecuencia heredó, y que su conducta parecía reflejar que aceptaba la situación jurídica establecida jurídicamente, el Tribunal entendió que tal conducta podría ser objeto de valoración y calificación en otros litigios que se pudieran plantear en materia sucesoria, pero no en el que versa sobre su filiación. La aceptación de una situación jurídica familiar no afecta a la acción de filiación, la cual es indisponible. Utilizar los tiempos con fines sucesorios no basta para considerar de abusiva o desleal una acción de filiación, aisladamente considerada (PROV 2015, 70609). 
nía usando desde su nacimiento. En todo caso, esta decisión del Tribunal no puede entenderse como una sanción al padre que ejercita tardíamente la acción de reclamación de filiación, sino como una medida de protección al menor al ser conocido en sus círculos sociales con el primer apellido materno. Así lo constata también el $\mathrm{TC}^{90}$ quien ha invocado de forma reiterada jurisprudencia del TJUE y del TEDH.

2. Las acciones de impugnación de filiación:

El artículo 136 CC se encarga de las acciones de impugnación de filiación matrimonial ya determinadas en el Registro Civil, y de la legitimación del marido de la madre del hijo correspondiente. De esta forma, al esposo se le otorga el plazo de un año desde la inscripción de la filiación en el Registro Civil. Ahora bien, el cómputo de ese año comenzará a contar cuando el marido conozca el nacimiento. A su vez, aunque el marido tuviera conocimiento del nacimiento pero desconociera su falta de paternidad, el año comenzará a contar desde que tuviere conocimiento. Esta regulación ha sido introducida con ocasión de la Ley 26/2015, de 28 de julio, de Modificación del Sistema de Protección a la Infancia y a la Adolescencia. En la anterior redacción dada por la Ley de 13 de mayo de 1981, este artículo ya fue objeto de algunas modificaciones. En la original redacción se establecía que el plazo de un año comenzaba a correr aunque el marido, conociendo el nacimiento, ignorara su falta de paternidad. Este primer párrafo fue anulado a través de la sentencia del TC núm. 138/2005, de 26 de mayo $^{91}$.

Antes de la reforma de este artículo, ya el TS aclaraba que el dies a $q u o$ viene dado por la existencia de un principio de prueba sobre la no paternidad biológica ${ }^{92}$. En este sentido, el TC, confirmó que la regla general es que el dies a quo de este plazo se sitúe en la fecha de inscripción del nacimiento ${ }^{93}$. En consecuencia, instó al legislador a admitir como excepción la posibilidad de que el marido impugnara en el momento en que extemporáneamente descubriera la falsedad y

${ }^{90}$ STC núm. 167/2013, de 7 de octubre (RTC 2013, 167).

${ }^{91}$ Suplemento del $B O E$ núm. 148, de 22 de junio. Posteriormente, la STC. núm. 156/2005, de 9 de junio (Suplemento del BOE núm. 162, de 8 de julio) estimó la cuestión de inconstitucionalidad 4203-2003, relativa a ese primer párrafo del art. 136 CC, remitiéndose a la sentencia núm. 138/2005, de 26 de mayo.

${ }_{92}$ STS, de 20 de febrero de 2012 (RJ 2012, 4047).

${ }^{93}$ Visto en la SAP de Pontevedra, de 8 de noviembre de 2013 (PROV 2013, 381110). 
no hubiera ni negligencia ni conocimiento implícito previo. Se afirma entonces que el dies a quo del plazo debe cifrarse no tanto en el conocimiento de la falsedad como en la cognoscibilidad. De esta forma, se tendrá por caduca la acción si el marido se mantuvo pasivo ante signos claros, que no meras sospechas, de su falta de paternidad ${ }^{94}$. Lo anterior, finamente, ha adquirido rango de ley con ocasión de la Ley $26 / 2015$, de 28 de julio.

En cuanto al plazo de ejercicio del hijo para impugnar la filiación ya determinada, se le otorga un año desde la inscripción de la filiación. Este año, en el caso de que el hijo sea menor de edad o incapaz, comenzará a contar desde que alcance la mayoría de edad o recobre la capacidad suficiente. También se le otorga la anterior posibilidad a la madre, representante legal o Ministerio Fiscal, durante la minoría de edad o tiempo en el permanezca con limitación de la capacidad. Independientemente de lo anterior, se contempla la posibilidad de que, ante todas esas situaciones, el hijo no hubiera impugnado la paternidad por desconocerla. En este caso se permite que el año de ejercicio comience desde que éste tuviera conocimiento de la falta de paternidad. A juicio de Díaz Martínez, la acción impugnatoria del hijo, debería quedar sometida a los mismos criterios de cómputo de plazo vistos para el caso del esposo. El artículo 137 CC habrá de ser interpretado en el mismo sentido que el $136 \mathrm{CC}$ en cuanto al criterio de cognoscibilidad.

Lo cierto es que, en la práctica, lo usual es la acumulación de esta acción de impugnación con la de reclamación de paternidad respecto del verdadero padre biológico. Esto diluye el tema de la caducidad de la acción, puesto que, como hemos visto, esa acción es imprescriptible para el hijo y la acción de impugnación se convierte en accesoria ${ }^{95}$

${ }^{94}$ A este respecto hay que tener en cuenta la sentencia del TS, de 2 de diciembre de 2013, en la que, con ese planteamiento de fondo, declaró caduca la acción de impugnación de filiación interpuesta por el progenitor legal, aplicando el principio de buena en el ejercicio de estas acciones de impugnación de filiación matrimonial. En este supuesto, el esposo, quien pasaba por una profunda crisis matrimonial durante el periodo de gestación del hijo, teniendo sospechas de que ese hijo era de un tercero, fue advertido por el ginecólogo del cauce para solventar sus dudas sobre su paternidad. El Supremo consideró en este caso que, dando entrada al principio de cognoscibilidad que exige una conducta activa y diligente por parte del marido, ante su impasividad, la acción debía considerarse extemporánea puesto que únicamente a él podía ser imputable. En definitiva, el cómputo para el ejercicio de la acción de impugnación matrimonial por parte del esposo no comienza desde que se tuvo prueba completa de la falta de paternidad biológica, sino desde que concurren indicios que no pueden ser ignorados sin incurrir en mala fe.

${ }^{95} \mathrm{El}$ TS establece que la acción de impugnación de filiación es accesoria a la de reclamación por ser ambas contradictorias y no poder subsistir conjuntamente. En 
de aquella. Además, como ya se ha señalado, en esta acción de reclamación de filiación no cabe el planteamiento del retraso desleal de la acción o el abuso del derecho por parte del hijo que reclama la filiación.

Todo lo anterior se refiere a casos en los que medió posesión de estado entre progenitor e hijo. Para las situaciones en las que, a pesar de tratarse de filiación matrimonial, faltó esa posesión de estado, se les otorga tanto a padre como a hijo la posibilidad de interponer la demanda en cualquier tiempo.

El artículo 140 CC, el cual también ha sufrido una modificación con ocasión de la Ley 26/2015, contempla que la filiación materna o paterna, no matrimonial, cuando falte la posesión de estado, podrá ser impugnada por quien le perjudique. En el caso de que sí exista posesión de estado, la acción podrá ser interpuesta por quien aparezca como hijo o progenitor en esa filiación, además de por las personas que puedan resultar afectados en su calidad de herederos forzosos. Se establece para ello un plazo de caducidad de cuatro años desde que el hijo goce de esa posesión de estado, una vez inscrita la filiación en el Registro Civil. En el caso de las acciones de impugnación, tal y como se ha expuesto, los plazos de interposición de las mimas se refieren a la posibilidad de rectificar la filiación que aparece en el Registro Civil al no entenderse verdadera. En el caso que nos afecta, que no es otro que la limitación de tiempo que le da al hijo, no entendemos que la legislación actual quebrante el derecho a conocer los orígenes biológicos, puesto que, aunque limite ese plazo a un año o cuatro, dependiendo del supuesto de hecho, el cómputo, en todo caso, podrá comenzar desde que el hijo, o sus representante legal, conozca la ausencia de paternidad de la persona que figura como tal en el Registro Civil, o desde que comience la posesión de estado.

\section{La legitimación de los herederos en la acciones de filiación:}

En cuanto a la titularidad del derecho a conocer los orígenes biológicos se discute si este derecho es referible únicamente al hijo o también al progenitor. Esto, en realidad, se centra en la legitimación que nuestro ordenamiento jurídico les otorga para el ejercicio de las acciones de filiación. En el caso que estamos tratando relativo a la filiación natural, nuestro legislador entendió que tanto el hijo como el

modo alguno puede admitirse aplicar a la acción de reclamación, que es la principal, el plazo de caducidad que el art. 137 prevé para la de impugnación. SSTS, de 17 de junio de 2004 (RJ 2004, 3618) y de 14 de diciembre de 2005 (RJ 2005, 10161). 
progenitor tienen derecho a investigar la verdad biológica. De igual forma, puede entenderse que el interés del progenitor en esa búsqueda puede hallarse en otros principios y razones, como puede ser encontrar un medio eficaz para cumplir su deber de prestación de asistencia ${ }^{96} \mathrm{y}$, de igual forma, poder disfrutar de los derechos respecto de ese hijo. Entendemos que, en materia de conocer los orígenes biológicos, la perspectiva de actuación debiera limitarse al círculo de protagonistas implicados en esa relación de filiación. Decimos esto desde un punto de vista crítico respecto a la legitimación otorgada por nuestro legislador a los "herederos" en materia de acciones de filiación. Como hemos visto, los artículos $132,133,136,137$ y 140 CC, mencionan como titulares de este interés a los herederos del hijo, al Ministerio Fiscal o incluso a los legitimarios del progenitor. Además de lo anterior, es importante constatar que el Código Civil, habla indistintamente de herederos, de herederos forzosos y de legitimarios ${ }^{97}$.

En este punto, si aceptamos la procedencia del derecho a conocer los orígenes biológicos, el círculo de legitimados, tal y como defiende García Vicente ${ }^{98}$, debe establecerse en razón de lazos biológicos y no en razón de lazos sucesorios ${ }^{99}$, puesto que, esto último implica un claro contenido patrimonial. Al menos, si el Código no establece una restricción, entendemos necesario que hable de «descendientes»

${ }^{96}$ GaRcía Vicente, J. R.: Los principios de las acciones de filiación, ob. cit., pág. 8.

${ }^{97}$ Respecto a las acciones de reclamación de paternidad, el artículo 132 CC habla de los herederos del hijo que fallece como legitimados para interponer la acción de reclamación de filiación. De igual forma, el artículo 133 CC legitima a los herederos del hijo por el tiempo que faltare de plazo legal y, a su vez, incluso a los herederos del progenitor, aunque en este caso se exige que la acción ya fuera interpuesta en vida por aquél. Respecto a las acciones de impugnación, el artículo 136 CC designa legitimación a los herederos del esposo fallecido y el $137 \mathrm{CC}$ a los herederos del hijo.

${ }^{98}$ García Vicente, J. R.: Los principios de las acciones de filiación, ob. cit., pág. 8.

${ }^{99}$ En este aspecto debemos mencionar la STEDH, de 5 de mayo de 2009 (TEDH 2009 , 49), relativa al caso Rocío Menéndez García contra España. La actora presentó demanda frente al Juzgado de Primera Instancia de Oviedo solicitando que su padre, fallecido en 1974, fuera reconocido como hijo biológico de V. T. A, igualmente fallecido. Señaló que su padre era hijo extramatrimonial de V. T. A y una de sus empleadas. La demanda se basó en la posesión de estado aportando a tal fin, elementos de prueba como fotografías y declaraciones de vecinos del pueblo que afirmaban que era sabido que el señalado era padre del menor. La demandante solicitó la exhumación del cadáver de su supuesto abuelo para la realización del análisis de ADN. En este caso, el Tribunal consideró que el interés por el conocimiento de la identidad varía en función del grado de parentesco de los ascendientes. Reconociendo que es de suma importancia conocer el origen de los ascendientes directos su peso en relación con otros intereses disminuye en función del alejamiento en grado de parentesco. El Tribunal entendió que no es igual el impacto en la vida privada del derecho a conocer a su padre que a su abuelo. 
y no de "herederos", puesto que en este concepto pueden claramente encuadrarse personas ajenas a la propia familia. ¿Qué sentido tiene otorgar legitimación para la búsqueda de orígenes biológicos a una serie de personas que no guardan relación consanguínea con los implicados?

Aun restringiendo la legitimación a los puros lazos de sangre, imaginemos los efectos que puede producir la muerte del actor respecto a la legitimación de otros familiares. Nos encontramos el supuesto de que otros descendientes (en el caso de herederos descendientes) sean titulares del mismo derecho. Esto significa que se extiende la posibilidad de conocer los orígenes más allá del propio progenitor. En palabras de García Vicente «(...) esta cuestión está afectada por tintes patrimoniales, o mejor, sucesorios, que deberían expulsarse de la regulación de esta materia» ${ }^{100}$. Los herederos pueden encuadrarse dentro de la línea sucesoria descendiente, pero también en la línea ascendiente. Dentro del concepto de «heredero» podemos encontrar también al cónyuge, tanto en la sucesión testada si así lo designó el causante para el tercio de libre disposición, o como heredero legal $a b$ intestato para el caso de que muriera intestado y sin línea descendiente o ascendiente. Dentro del derecho sucesorio, también podemos encontrarnos con supuestos en los que resultan sucesores, primos, tíos, sobrinos, o demás familiares de distinto grado de parentesco, o incluso amigos o demás terceros designados por la libre voluntad por el testador.

¿Debe tener cualquier heredero legitimación para interponer una acción de filiación, basada en el fin jurídico de la búsqueda de la verdad biológica? Respondemos a esta pregunta claramente en negativo. Si el legislador no pone restricción a esta legitimación, al menos debería limitarlo al término "descendientes».

\section{CONCLUSIONES: REFORMA DEL DERECHO:}

En la regulación relativa al derecho a conocer los orígenes biológicos y, en definitiva, al derecho a la libre investigación de la paternidad, creemos que ha llegado el momento de implantar en España una serie de reformas legislativas que refuercen el mismo, con el objetivo de otorgar mayores garantías que potencien la seguridad jurídica. De esta forma, entendemos que en relación con el criterio

${ }^{100}$ García Vicente, J. R.: Los principios de las acciones de filiación, ob. cit., pág. 9. 
legislativo del control de viabilidad previo que el legislador defiende para la interposición de cualquier demanda de paternidad, queda salvado desde el momento en que nuestros tribunales aceptan, de forma casi unánime, la oferta de la prueba biológica como garante de posibilidad de concepción. En todo caso, creemos necesario que siempre que se ofrezca la realización de prueba biológica, el juez o tribunal correspondiente debería admitir a trámite la demanda de forma imperativa. Esto supone la necesidad de una modificación legislativa del art. 767 LEC, lo que en realidad significa darle de forma definitiva valor de rango de ley a un consolidado criterio jurisprudencial.

En relación a los efectos de la negativa del demandado a someterse a la prueba biológica, el conflicto queda salvado con la conceptuación de esta negativa como un indicio valiosísimo y muy cualificado que, junto a otros indicios de posibilidad de relación sexual en la época de la concepción, puede determinar la filiación a través de sentencia. En todo caso, como ya hemos señalado, entendemos que es necesario que siempre que la parte interesada ofrezca la práctica de la prueba de ADN, el tribunal competente debe aceptar su práctica de forma imperativa. Teniendo la posibilidad de prueba directa, y de que el propio demandado acredite la verdad con una muestra simple de saliva, creemos que debería ser acordado de forma ineludible en los procesos de filiación. Como no puede imponerse el sometimiento a la misma de forma coercitiva, el demandado deberá asumir esa negativa como un valioso indicio de paternidad.

En cuanto a la cuestión relativa a los plazos preclusivos de las acciones de reclamación de filiación, tanto para los supuestos de filiación matrimonial como no matrimonial sin posesión de estado, el plazo para el hijo es imprescriptible. En consecuencia, se protege el derecho a la búsqueda de la paternidad. Respecto a los plazos para las acciones de impugnación, aunque se limita su ejercicio a uno y a cuatro años, el hijo queda protegido desde el momento en que se permite que el cómputo de los mismos comience en el momento en que éste conoce la falta de paternidad real del progenitor filiado, o desde que, una vez inscrito, comienza la situación relativa a la posesión de estado.

Por último, en lo que se refiere a la legitimación de los herederos del hijo, o del progenitor implicado, entendemos necesaria una reforma de los preceptos relativos a las acciones de filiación (132-140 CC) por la que se sustituya el término "herederos" por

(C) UNED. Revista de Derecho UNED, núm. 21, 2017 
«descendientes». Creemos que el conocimiento de la búsqueda de la paternidad no debe quedar en manos de una amplia legitimación sino que, por el contrario, debe limitarse a un círculo unido por lazos de sangre en línea recta descendiente. De lo contrario, se permite que el fin de las acciones de filiación quedé reflejado en el interés por los derechos sucesorios, más que por la búsqueda de la verdad biológica.

\section{BIBLIOGRAFÍA}

Bujosa VAdELL, L.: «El alcance de la obligación de sometimiento a las pruebas biológicas en los procesos de filiación (en torno a la STC 7/1994, de 17 de enero)». RGD, 1996.

CARBAJo GonZÁLEZ, J.: «Las acciones de impugnación de la filiación en la jurisprudencia (a propósito de la sentencia del TS de 5 de junio de 1997)». AC, doctrina VIII, 2000.

Cordero Cutillas, I.: «La impugnación de la paternidad matrimonial». Colección de Estudios Jurídicos de la Universidad Jaime I, núm. 6, Castellón, 2001.

Díaz Martínez, A.: «Buena fe, retraso desleal y actos propios en el ejercicio de las acciones de filiación». Aranzadi, Civil-Mercantil, núm. 4/2015, Parte Comentario, 2015.

Díez Picazo, L., Gulllón Ballesteros, A.: Sistema de Derecho Civil. Derecho de Familia y Derecho de Sucesiones. Tecnos, Vol. IV, 10. ${ }^{a}$ ed., 2006.

Durán RIVAcoBA, R. «El anonimato del progenitor». Revista Doctrinal Aranzadi, Civil-Mercantil, núm. 3, Parte Estudio, Pamplona, 2004.

ETXEBERRÍA GURIDI, J. F., «La negativa al sometimiento a las pruebas biológicas de filiación y la STC 95/1999, de 31 de mayo, ¿una renuncia a postulados anteriores?». AC, 2000.

García Poveda, C. Las pruebas biológicas en los procesos de filiación. Cómo se soluciona la negativa del sujeto a la práctica de las pruebas de ADN. NJ Bosch, 2003.

GARCía VicENTE, J. R.: Los principios de las acciones de filiación. Aranzadi, Pamplona, 2004.

González Pérez De CASTRo, M.: La verdad biológica en la determinación de la filiación, Dykinson, Madrid, 2013. 
Kemelmajer de Carlucci, A., Herrera, M., Lamm, E., en «Ampliando el campo del derecho filial en el derecho argentino. Texto y contexto de las técnicas de reproducción humana asistida». Revista de Derecho Privado, Argentina, núm. 1, 2012.

LinACERo de LA Fuente, M.: «Derecho a la identidad personal: el nombre y los apellidos», en Derecho Civil IV. Introducción al Derecho Civil, Tirant lo Blanch, Valencia, 2013.

LóPez Gálvez y Moreno García: “¿"Industria de la fertilidad” o respuesta a la búsqueda del hijo biológico?» en «Treinta años de reproducción asistida en España: una mirada interdisciplinaria a un fenómeno global y actual». Boletín del Ministerio de Justicia, Monográfico, Año LXIX, núm. 2179, junio 2015.

LORENTE LóPEZ, M. ${ }^{a}$, C. «La prueba genética y los derechos fundamentales de la persona en los procesos civiles de filiación, paternidad y maternidad». Revista Doctrinal Aranzadi, Cizur Menor, 2015.

MAYOR DEL Hoyo, M. ${ }^{a}$ V.: «Sobre la intervención del defensor judicial en los procesos de impugnación de la paternidad (comentario a la STS 481/1997, de 5 de junio)». ADC, 1998.

Moreno Martínez, J. A.: «Comentario a la sentencia del TS de 5 de junio de 1997». CCJC, núm. 45, 1997.

Moro Almaraz, M. J.: «Comentario a la sentencia del Tribunal Constitucional 7/1994, de 17 de enero». CCJC, núm. 34, 1994.

OcaÑa Rodríguez, A. «La sentencia del Tribunal Constitucional de 17 de enero de 1994 sobre filiación, desde una perspectiva procesal». PJ, núm. 36, 1994.

ORdóÑEZ FERNÁNDEZ, C.: «Pruebas biológicas de paternidad. Estudio crítico de la prueba pericial. Garantías de la prueba y su incidencia en la determinación de la decisión judicial». La Ley, núm. 2, 1995.

Quesada GonzÁlez, M. ${ }^{a}$ C.: «La prueba de ADN en los procesos de filiación». Anuario de Derecho Civil, II, 2005.

Quicios Molina, S.: «Determinación e impugnación de la filiación». Cuadernos Aranzadi Civil-Mercantil, 2014.

ROCA TRÍAS, E.: «Filiación asistida y protección de derechos fundamentales». Derecho y Salud, núm. 7, 1999.

RUBIDO DE LA TORRE, C.: «La investigación de la paternidad en el derecho vigente. La prueba biológica y las consecuencias de su negativa». $R G D, 1995$. 
Ruiz Moreno, J. M.: El proceso especial de filiación, paternidad y maternidad. La Ley, Madrid, 2000.

Tamayo Haya, S.: «Reproducción Asistida, doble maternidad legal y novedades jurisprudenciales en la determinación de la filiación» en La maternidad y la Paternidad en el siglo XXI. Comares, 2015. 